This document was prepared in conjunction with work accomplished under Contract No. DE-AC09-96SR18500 with the U. S. Department of Energy.

\title{
DISCLAIMER
}

This report was prepared as an account of work sponsored by an agency of the United States Government. Neither the United States Government nor any agency thereof, nor any of their employees, makes any warranty, express or implied, or assumes any legal liability or responsibility for the accuracy, completeness, or usefulness of any information, apparatus, product or process disclosed, or represents that its use would not infringe privately owned rights. Reference herein to any specific commercial product, process or service by trade name, trademark, manufacturer, or otherwise does not necessarily constitute or imply its endorsement, recommendation, or favoring by the United States Government or any agency thereof. The views and opinions of authors expressed herein do not necessarily state or reflect those of the United States Government or any agency thereof.

This report has been reproduced directly from the best available copy.

Available for sale to the public, in paper, from: U.S. Department of Commerce, National Technical Information Service, 5285 Port Royal Road, Springfield, VA 22161, phone: (800) 553-6847, fax: (703) 605-6900

email: orders@ntis.fedworld.gov

online ordering: http://www.ntis.gov/help/index.asp

Available electronically at http://www.osti.gov/bridge

Available for a processing fee to U.S. Department of Energy and its contractors, in paper, from: U.S. Department of Energy, Office of Scientific and Technical Information, P.O. Box 62, Oak Ridge, TN 37831-0062,

phone: (865)576-8401,

fax: (865)576-5728

email: $\underline{\text { reports@ adonis.osti.gov }}$ 
WSRC-TR-2003-00295, REV. 0

SRT-RPP-2003-00137, REV. 0

\section{FILTRATION OF A HANFORD AN-104 SAMPLE (U)}

AUGUST 7, 2003

Savannah River Technology Center

Westinghouse Savannah River Company Savannah River Site Aiken, SC 29808 
Key Words:

Filtration

Washing

Leaching

Retention:

Permanent

Key WTP R\&T References:

Test Specification: 24590-PTF-TSP-RT-02-011

Test Plan: WSRC-TR-2002-00507

Test Exceptions: None

R\&T Focus Area: Ultrafiltration

Test Scoping Statement(s): S-147

\title{
FILTRATION OF A HANFORD AN-104 SAMPLE (U)
}

\author{
Michael R. Poirier, SRTC \\ Paul Burket, SRTC \\ Jeffrey L. Siler, SRTC
}

Issue Date: September 12, 2003

Westinghouse Savannah River Company Savannah River Site

Aiken, SC 29808

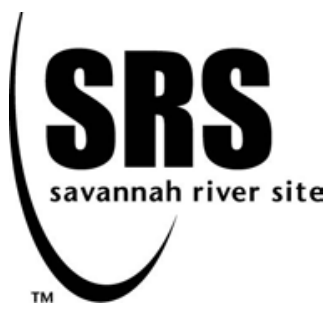




\section{TABLE OF CONTENTS}

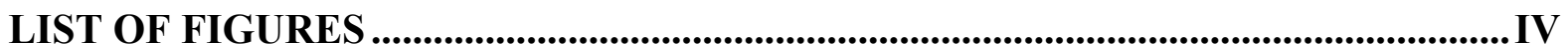

LIST OF TABLES ...................................................................................................................... IV

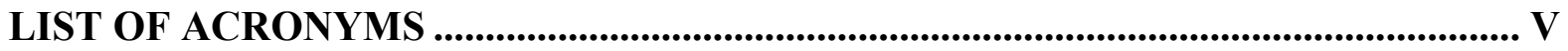

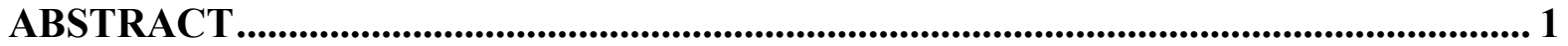

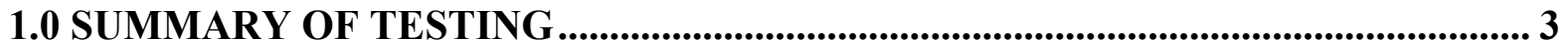

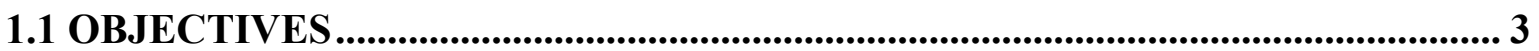

1.2 CONDUCT OF TESTING................................................................................................ 3

1.3 RESULTS AND PERFORMANCE AGAINST OBJECTIVES ................................. 4

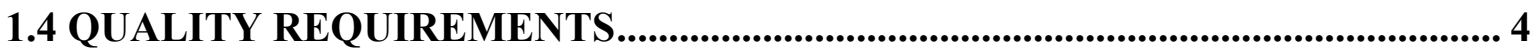

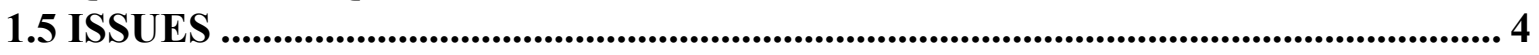

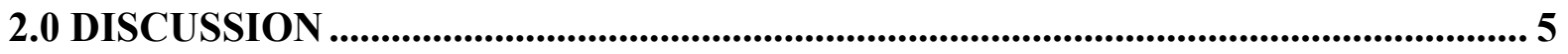

2.1 INTRODUCTION .......................................................................................................... 5

2.2 EXPERIMENTS.......................................................................................................... 5

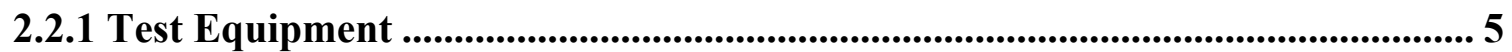

2.2.2 Test Preparation ....................................................................................................... 6

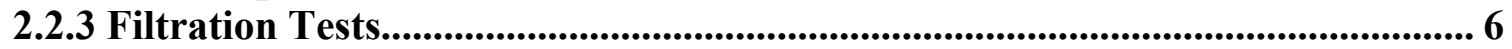

2.2.4 Washing Test ....................................................................................................................... 8

2.2.5 Sample Preparation and Analysis.............................................................................. 9

2.3 RESULTS .......................................................................................................................... 12

2.3.1 Filtration Test Results................................................................................... 13

2.3.2 Washing Results ............................................................................................................ 15

2.3.3 Analytical Results.......................................................................................... 17

2.3.3.1 Particle Size Data .................................................................................................... 17

2.3.3.2 Filtrate Data ............................................................................................................ 17

2.3.3.3 Unwashed Solids Data ..................................................................................... 20

2.3.3.4 Concentrated, Washed Slurry Data ....................................................................... 21

2.3.4 Rheology .................................................................................................................... 23

2.3.5 Density and Solids Concentration................................................................................. 24

2.3.6 Filter Cleaning .................................................................................................................. 24

3.0 FUTURE WORK ............................................................................................................ 27

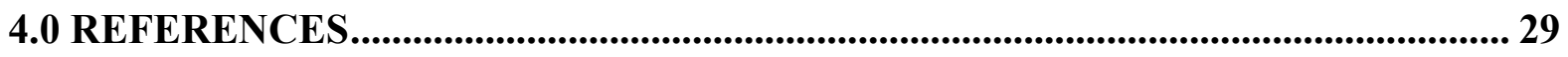

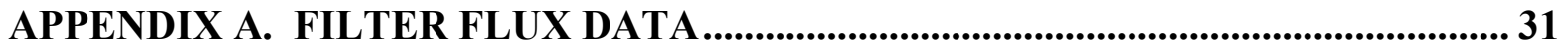

APPENDIX B. FILTER FLUX STATISTICAL DATA ....................................................... 33

APPENDIX C. ANALYTICAL REQUIREMENTS ............................................................ 35

APPENDIX D. SCANNING ELECTRON MICROSCOPE PICTURES OF SOLIDS

PARTICLES.............................................................................................................................. 37 


\section{LIST OF FIGURES}

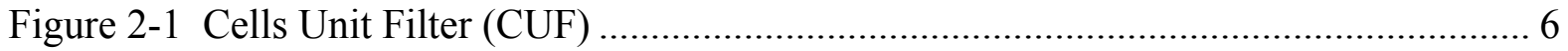

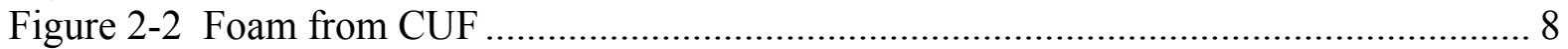

Figure 2-3 Filter Flux During Dewatering ................................................................. 13

Figure 2-4 Filter Flux of 0.9 wt.\% AN-104 Slurry ...................................................... 14

Figure 2-5 Filter Flux of 0.9 wt.\% AN 104 Slurry .......................................................... 14

\section{LIST OF TABLES}

Table 2-1 Filtration Test Matrix Conditions ..................................................................... 7

Table 2-2 Radionuclides and Chemical Constituents ......................................................... 10

Table 2-3 Clean Water and Strontium Carbonate Flux ................................................ 13

Table 2-4 Washing Sample Results ............................................................................ 15

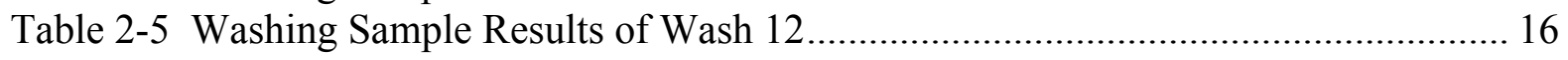

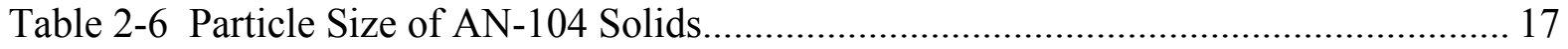

Table 2-7 Chemical Composition of Filtrate Samples.................................................... 18

Table 2-8 Filtrate vs. Washed Filtrate Anion-Organic Data.............................................. 20

Table 2-9 Chemical Composition of Unwashed Solids Sample by Water Leach ................ 20

Table 2-10 Chemical Composition of Final Solids Sample by Acid Digestion ................... 22

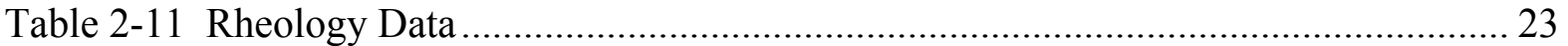

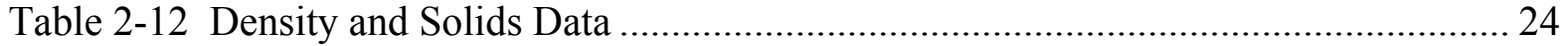

Table 2-13 Filter Cleaning Data ............................................................................ 25 


\section{LIST OF ACRONYMS}

$\begin{array}{ll}\text { AA } & \text { Atomic Absorption } \\ \text { CUF } & \text { Cells Unit Filter } \\ \text { CVAA } & \text { Cold Vapor Atomic Absorption } \\ \text { HLW } & \text { High Level Waste } \\ \text { IC } & \text { Ion Chromatography } \\ \text { ICPES } & \text { Inductively Coupled Plasma Emission Spectroscopy } \\ \text { ICPMS } & \text { Inductively Coupled Plasma Mass Spectroscopy } \\ \text { LAW } & \text { Low Activity Waste } \\ \text { LIMS } & \text { Laboratory Information Management System } \\ \text { N/A } & \text { Not Applicable } \\ \text { PUTTA } & \text { Plutonium Triphenyl Trifluoro Acetone } \\ \text { RPP } & \text { River Protection Project } \\ \text { SEM } & \text { Scanning Electron Microscope } \\ \text { SRTC } & \text { Savannah River Technology Center } \\ \text { TDS } & \text { Total Dissolved Solids } \\ \text { TIC } & \text { Total Inorganic Carbon } \\ \text { TOC } & \text { Total Organic Carbon } \\ \text { TC } & \text { Total Carbon } \\ \text { TIS } & \text { Total Insoluble Solids } \\ \text { TMP } & \text { Transmembrane Pressure } \\ \text { WTP } & \text { Waste Treatment Plant }\end{array}$


WSRC-TR-2003-00295, REV. 0

SRT-RPP-2003-00137, REV. 0

This page intentionally left blank. 


\begin{abstract}
The Savannah River Technology Center (SRTC) conducted ultrafiltration tests with samples from the Hanford Site's AN-104 tank. The test objectives were to measure filter flux during dewatering and the removal of soluble species during washing.

The filtration tests were conducted with the Cells Unit Filter (CUF) currently installed in Cell 16 of the SRTC High Activity Caves. Following filtration, personnel performed inhibited water washing to remove soluble species. Because of the limited volume of concentrated slurry, the washing was performed with a volumetric flask rather than a crossflow filter. Following the washing, personnel chemically cleaned the filter with $1 \mathrm{M}$ nitric acid and periodically measured the clean water flux.

The results of the testing follow.

- The average measured flux of $0.085 \mathrm{gpm} / \mathrm{ft}^{2}$ during dewatering exceeded the target of $0.03 \mathrm{gpm} / \mathrm{ft}^{2}$. Note that a low insoluble solids content of only $0.9 \mathrm{wt} \%$ contributed to the high average flux.

- A statistically significant correlation was observed between filter flux and transmembrane pressure.

- The measured mean particle size was $0.8-1.7$ micron.

- The filtrate viscosity measured $3.5 \mathrm{cp}$, and the slurry viscosity measured $3.9 \mathrm{cp}$ at 0.9 wt $\%$ insoluble solids. The washed filtrate viscosity measured $1.3 \mathrm{cp}$. The washed slurry was concentrated to $2.2 \mathrm{wt} \%$ insoluble solids. Its viscosity measured $1.9 \mathrm{cp}$ with a yield stress of $1.47 \mathrm{~Pa}$.
\end{abstract}


WSRC-TR-2003-00295, REV. 0

SRT-RPP-2003-00137, REV. 0

This page intentionally left blank. 


\subsection{SUMMARY OF TESTING}

\subsection{OBJECTIVES}

The SRTC conducted ultrafiltration tests with a sample from the AN-104 tank. The test objectives were to measure filter flux during dewatering and the removal of soluble species during washing. Single tube crossflow filtration tests produced indicative data on equipment performance (permeate flux).

\subsection{CONDUCT OF TESTING}

Filtration tests were conducted with the CUF currently installed in Cell 16 of SRTC High Activity Caves. The unit has a $2 \mathrm{ft}$ long stainless steel Mott crossflow filter of $3 / 8$ " ID and 0.1 micron nominal pore size. The system can provide up to $16.5 \mathrm{ft} / \mathrm{s}$ crossflow velocity, along with up to 80 psi transmembrane pressure (TMP). Feed from the reservoir passes through a progressive cavity pump. The pump is operated at variable speed by controlling the air pressure supplied to the pump motor. The slurry is pumped through a magnetic flow meter and heat exchanger to remove heat. Ice water, contained in a 3-gallon Igloo cooler, removes heat from the system. The slurry then passes through the crossflow filter. A throttle valve downstream of the filter is used to adjust the filter TMP. The filtrate flow rate is measured with a calibrated sight glass and stopwatch. The system is equipped with a manual backpulse system. The feed, concentrate, and filtrate pressures are measured with standard Bourdon-type pressure gauges. A thermocouple mounted near the bottom of the feed reservoir measures the slurry temperature.

The feed sample for the tests was an AN-104 actual waste sample previously adjusted to $5 \mathrm{M}$ sodium. ${ }^{3}$

During the testing, personnel controlled the feed slurry temperature to $25^{\circ} \mathrm{C}$. The axial velocity and transmembrane pressure were controlled to Hanford Waste Treatment Plant (WTP) personnel-specified values. ${ }^{1}$ Filtrate flux data was collected periodically.

Following filtration, personnel performed inhibited water washing to remove soluble species. Because of the limited volume of concentrated slurry, the washing was performed with a $100 \mathrm{~mL}$ volumetric flask rather than a crossflow filter.

Following the washing, personnel chemically cleaned the filter with $1 \mathrm{M}$ nitric acid and periodically measured the clean water flux. 


\subsection{RESULTS AND PERFORMANCE AGAINST OBJECTIVES}

The objectives and success criteria for this task follow. ${ }^{1}$

- The product stream before and after washing contains $20 \mathrm{wt}$. \% insoluble solids with compatible (will it pump or not) slurry rheology. The feed sample contained insufficient volume to reach $20 \mathrm{wt}$. \% solids in the filtration test equipment. Therefore, the researchers cannot determine if $20-25 \mathrm{wt} \%$ insoluble solids slurries have compatible slurry rheology.

- No solids pass into the ultrafiltration permeate. No solids were observed in filtrate samples.

- Average flux is $>0.03 \mathrm{gpm} / \mathrm{ft}^{2}$ during dewatering. The average filter flux during dewatering was $0.085 \mathrm{gpm} / \mathrm{ft}^{2}$, which is greater than the minimum flux.

- The wash factors for five AN-104 anions were determined and are shown in Table 2.8 .

- Researchers could not return the filtration equipment to pre-test operating levels following cleaning with inhibited water and $1 \mathrm{M}$ nitric acid.

\subsection{QUALITY REQUIREMENTS}

This work was conducted in accordance with the RPP-WTP QA requirements specified for work conducted by SRTC as identified in DOE IWO MOSRLE60. SRTC has provided matrices to WTP demonstrating compliance of the SRTC QA program with the requirements specified by WTP. Specific information regarding the compliance of the SRTC QA program with RW-0333P, Revision 10, NQA-1 1989, Part 1, Basic and Supplementary Requirements and NQA-2a 1990, Subpart 2.7 is contained in these matrices.

The specific quality requirements for this task are described in the Task Technical and Quality Assurance Plan. ${ }^{2}$

The measuring and test equipment used in the testing is in compliance with the SRS QA Program.

The methods used for performing the work and the data obtained from the work are reported in Laboratory Notebook WSRC-NB-2003-00031, “AN-104 CUF Filtration”.

The data collected and reported was verified by independent checking (Procedure E7, 2.31).

\subsection{ISSUES}

- Nitric acid cleaning. Personnel could not effectively clean the filter with $1 \mathrm{M}$ nitric acid. Following cleaning with four batches of inhibited water, five batches of $1 \mathrm{M}$ nitric acid, and two batches of $0.01 \mathrm{M}$ nitric acid, the filter flux remained significantly below the pre-run fluxes.

- A stable foam was formed in the CUF that overflowed the slurry tank and slurry tank sight glass during dewatering. 


\subsection{DISCUSSION}

\subsection{INTRODUCTION}

The WTP Research \&Technology Plan identified a sample from AN-104 tank as one of the waste solutions to be used to perform the filtration and sludge washing tests using the bench scale crossflow ultrafiltration unit (the CUF). ${ }^{1}$ Washing tests were performed to assess the reduction in quantity of High Level Waste (HLW) by removing soluble components.

SRTC personnel characterized the waste sample. That work is described in the AN-104 Characterization Task Plan. ${ }^{2}$ Following characterization, SRTC personnel processed that waste sample through the CUF to provide filter flux data, and washed the concentrated solids to provide design verification data to WTP. After the filtration testing, they chemically cleaned the filter with $1 \mathrm{M}$ nitric acid.

\subsection{EXPERIMENTS}

\subsubsection{Test Equipment}

Filtration tests were conducted with the CUF currently installed in Cell 16 of SRTC High Activity Caves (see Figure 2-1). The unit has a $2 \mathrm{ft}$ long stainless steel Mott crossflow filter of 3/8" ID and 0.1 micron nominal pore size. The system can provide up to $16.5 \mathrm{ft} / \mathrm{s}$ crossflow velocity, along with up to 80 psi TMP. Feed from the reservoir passes through a progressive cavity pump. The pump is operated at variable speed by controlling the air pressure supplied to the pump motor. The slurry is pumped through a magnetic flow meter and heat exchanger that removes heat. Ice water, contained in a 3-gallon Igloo cooler, removes heat from the system. The slurry then passes through the crossflow filter. A throttle valve downstream of the filter is used to adjust the filter feed pressure. The filtrate flow rate is measured with a sight glass and calibrated stopwatch. The system is equipped with a manual backpulse system. The feed, concentrate, and filtrate pressures are measured with standard Bourdon-type pressure gauges. A thermocouple mounted near the bottom of the feed reservoir measures the slurry temperature. 


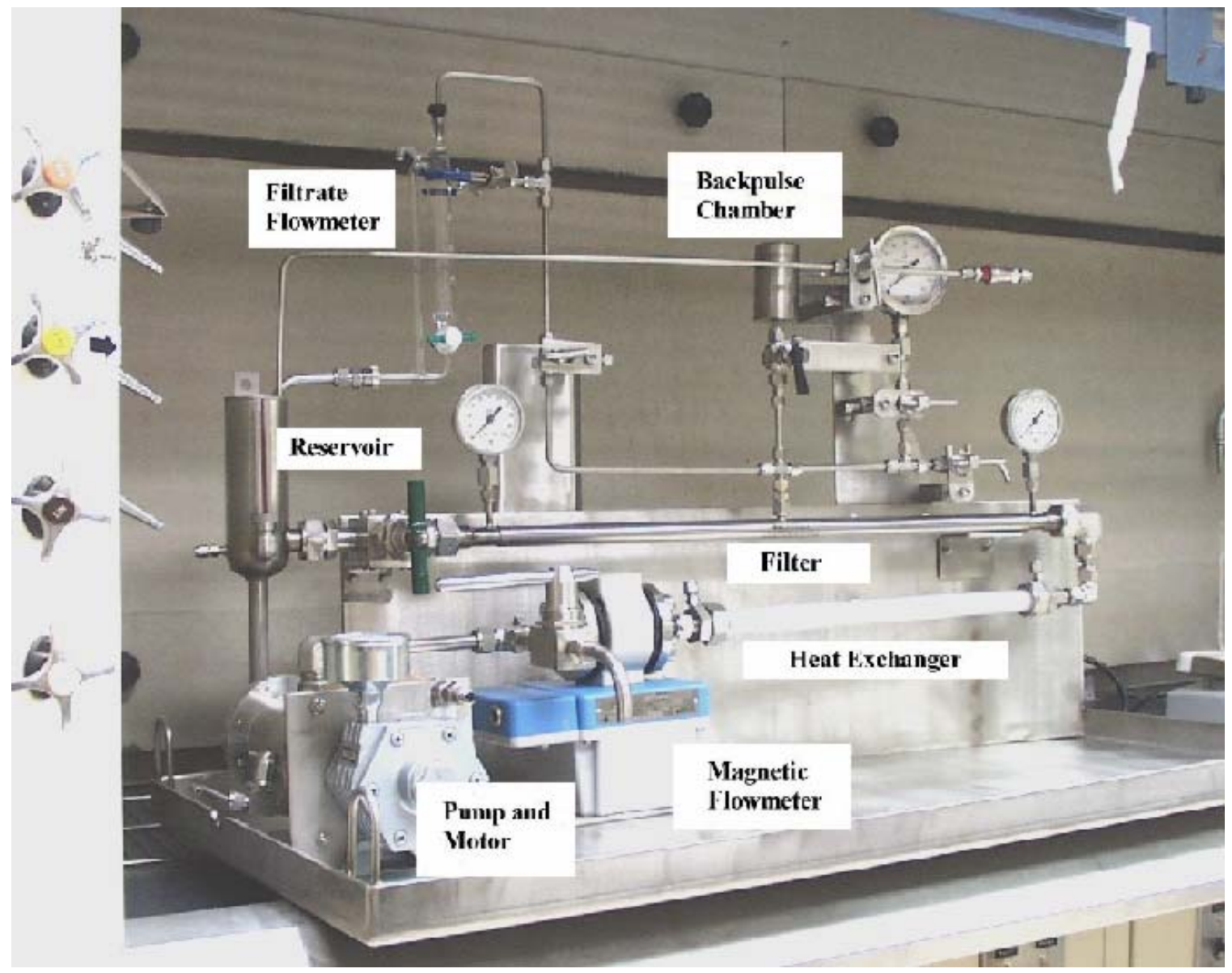

Figure 2-1 Cells Unit Filter (CUF)

\subsubsection{Test Preparation}

Researchers received a $6200 \mathrm{~mL}$ sample of Hanford AN-104 waste from the Characterization Team. ${ }^{3}$ The sample contained $5 \mathrm{M}$ sodium prior to the start of the filtration tests.

\subsubsection{Filtration Tests}

Personnel performed clean water flux tests with $0.01 \mathrm{M} \mathrm{NaOH}$ solution that was filtered through a 0.1 micron filter. The tests were performed at $11 \mathrm{ft} / \mathrm{s}$ axial velocity and 10 and 20 psi TMP. Following the clean water flux tests, personnel performed tests with $5 \mathrm{wt}$. \% strontium carbonate at $11 \mathrm{ft} / \mathrm{s}$ axial velocity and 10, 20, and $30 \mathrm{psi}$ TMP. Following the strontium carbonate test, they performed an additional clean water flux test at $11 \mathrm{ft} / \mathrm{s}$ axial velocity and 20 psi TMP. 
Personnel added 4.7 liters of AN-104 slurry to the filter feed tank. They concentrated the feed slurry from $\sim 0.07 \mathrm{wt}$. $\%$ to $\sim 0.9 \mathrm{wt}$. $\%$ by reducing its volume. The dewatering step lasted 12 hours. During the dewatering process, the axial velocity was $11 \mathrm{ft} / \mathrm{s}$, and the transmembrane pressure was 40 psi. Following the dewatering process, personnel conducted filtration matrix tests with the conditions shown in Table 2-1. Due to equipment limitations, three of the test conditions could not be met. Since the TMP has a greater effect on filter flux, the TMP was met at the expense of somewhat lower axial velocities for those three test conditions (See Appendix 2)

$\begin{array}{cc}\begin{array}{c}\text { Table 2-1 Filtration Test Matrix Conditions } \\ \text { TMP (psi) }\end{array} & \begin{array}{c}\text { Axial Velocity (ft/s) } \\ 40\end{array} \\ 40 & 11 \\ 40 & 11 \\ 30 & 11 \\ 30 & 9 \\ 50 & 13 \\ 50 & 13^{*} \\ 40 & 9 \\ 40 & 11 \\ 40 & 7 \\ 20 & 15^{*} \\ 60 & 11 \\ 40 & 11^{*} \\ * \text { Could not achieve target velocity }\end{array}$


About midway through the dewatering step, a stable foam was formed in the CUF and overflowed both the slurry tank and the slurry tank level sight glass. Foaming continued until the end of the dewatering step. No addition foaming occurred during the matrix flow tests. Figure 2-2 is a photograph of the foam at the end of the dewatering test. The equipment configuration with the small slurry tank may contribute to the occurrence of foam. This foam was still present five days later when it was rinsed off the unit with water. Further study would be required to determine the effect of foam on filter flux.

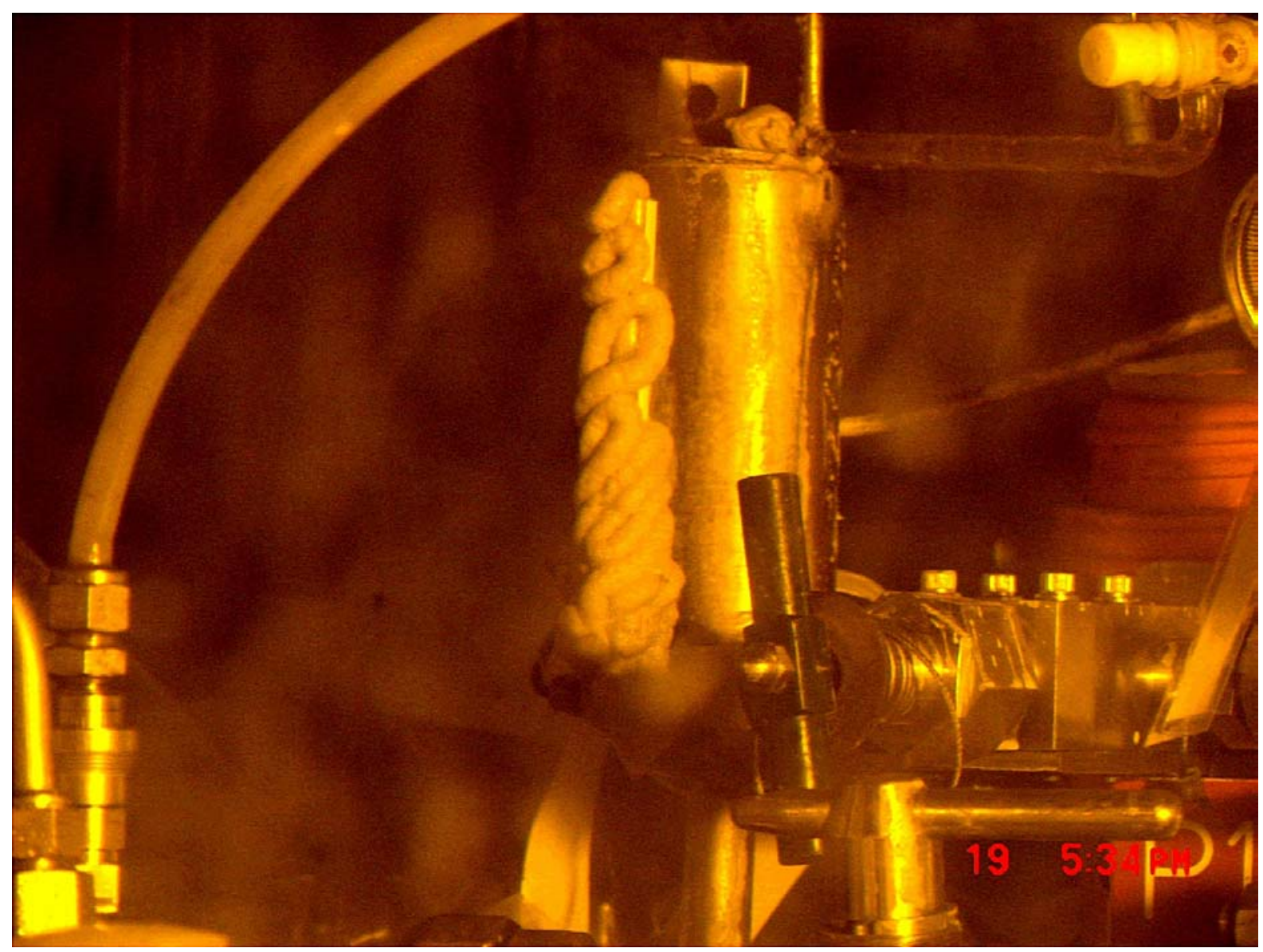

Figure 2-2 Foam from CUF

\subsubsection{Washing Test}

Because of the low volume of solids in the feed slurry, $94 \mathrm{~mL}$ of the $500 \mathrm{~mL}$ of feed slurry were decanted into a $100 \mathrm{~mL}$ volumetric flask. The washing process was performed in the volumetric flask rather than with the CUF. 
To perform the wash, personnel added $9.5 \mathrm{~mL}$ of inhibited water to the slurry in the volumetric flask. They capped the flask and inverted and shook it to contact the slurry and wash water. The flask was then set in a pan to allow the solids to separate from the liquid by settling. Following the settling, $9.5 \mathrm{~mL}$ liquid was removed with a disposable pipette that had a "stop" attached to it that would only allow it to go so far down into the volumetric flask.

Personnel repeated this process for a total of twelve washes.

\subsubsection{Sample Preparation and Analysis}

During the testing, SRTC collected the following samples and performed the specified analyses.

- Unwashed Slurry following dewatering

- TIC/TOC, IC(anions), rheology, insoluble solids, particle size

- Filtrate at the start of dewatering

- Radionuclides and chemical constituents in Table 2-2, soluble solids, rheology, density

- $\quad$ Filtrate from wash 1 , wash 4 , and wash 8

- Sodium, Cs-137

- $\quad$ Filtrate from washes 2,3,5,6,7,9-11

- Sodium

- Filtrate from wash 12 (final wash)

- Radionuclides and chemical constituents in Table 2-2, soluble solids

- Final solids slurry

- Radionuclides and chemical constituents in Table 2-2, insoluble solids, rheology

Table 2-2 shows the analyses performed on slurry, filtrate, and wash solutions, along with the method used to perform the analysis. 
WSRC-TR-2003-00295, REV. 0

SRT-RPP-2003-00137, REV. 0

Table 2-2 Radionuclides and Chemical Constituents

\begin{tabular}{|c|c|c|c|}
\hline Analyte & $\underline{\text { Solids }}$ & Filtrate, Wash Solutions & Method \\
\hline Cesium-137 & $\mathrm{X}$ & $\mathrm{X}$ & Gamma counting \\
\hline Strontium-90 & $\mathrm{X}$ & $\mathrm{X}$ & Sr separation by Eichrom resin \\
\hline Technetium-99 & $\mathrm{X}$ & $\mathrm{X}$ & $\begin{array}{l}\text { Eichrom disk separation, gamma } \\
\text { counting, liquid scintillation counting }\end{array}$ \\
\hline Americium-241 & $\mathrm{X}$ & $\mathrm{X}$ & Cs removal, gamma count \\
\hline Europium-154 & $\mathrm{X}$ & $\mathrm{X}$ & Cs removal, gamma count \\
\hline Europium-155 & $\mathrm{X}$ & $\mathrm{X}$ & Cs removal, gamma count \\
\hline $\mathrm{Pu}-239 / 240$ & $\mathrm{X}$ & $\mathrm{X}$ & PUTTA \\
\hline Total Alpha & $\mathrm{X}$ & $X$ & Cs removal, proportional counting \\
\hline Total Beta & $\mathrm{X}$ & $\mathrm{X}$ & Rad screen \\
\hline $\mathrm{Ag}$ & $\mathrm{X}$ & $\mathrm{N} / \mathrm{A}$ & ICPES \\
\hline $\mathrm{Al}$ & $\mathrm{X}$ & $X$ & ICPES \\
\hline $\mathrm{Ba}$ & $\mathrm{X}$ & $\mathrm{X}$ & ICPES \\
\hline $\mathrm{Ca}$ & $X$ & $\mathrm{X}$ & ICPES \\
\hline $\mathrm{Cd}$ & $\mathrm{X}$ & $\mathrm{X}$ & ICPES \\
\hline $\mathrm{Co}$ & $\mathrm{X}$ & $\mathrm{X}$ & ICPMS \\
\hline $\mathrm{Cr}$ & $\mathrm{X}$ & $\mathrm{X}$ & ICPES \\
\hline $\mathrm{Cu}$ & $\mathrm{X}$ & $\mathrm{X}$ & ICPES \\
\hline $\mathrm{Fe}$ & $X$ & $\mathrm{X}$ & ICPES \\
\hline $\mathrm{Hg}$ & $* *$ & N/A & CVAA \\
\hline $\mathrm{K}$ & $\mathrm{X}$ & $X$ & $\mathrm{AA}$ \\
\hline $\mathrm{La}$ & $\mathrm{X}$ & $\mathrm{X}$ & ICPES \\
\hline $\mathrm{Mg}$ & $X$ & $\mathrm{X}$ & ICPES \\
\hline $\mathrm{Mn}$ & $\mathrm{X}$ & $\mathrm{X}$ & ICPES \\
\hline Mo & $X$ & $\mathrm{X}$ & ICPES, ICPMS \\
\hline $\mathrm{Na}$ & $\mathrm{X}$ & $\mathrm{X}$ & ICPES, AA \\
\hline $\mathrm{Ni}$ & $\mathrm{X}$ & $\mathrm{X}$ & ICPES \\
\hline $\mathrm{Pb}$ & $\mathrm{X}$ & $\mathrm{X}$ & ICPES \\
\hline $\mathrm{Si}$ & $\mathrm{X}$ & $\mathrm{X}$ & ICPES \\
\hline $\mathrm{Sr}$ & $X$ & $X$ & ICPES \\
\hline $\mathrm{Ti}$ & $X$ & $\mathrm{X}$ & ICPES \\
\hline $\mathrm{U}$ & $X$ & $\mathrm{X}$ & ICPES, ICPMS \\
\hline $\mathrm{Zn}$ & $X$ & $\mathrm{X}$ & ICPES \\
\hline TOC & $* *$ & $\mathrm{X}$ & TIC/TOC \\
\hline TIC & $* *$ & $\mathrm{X}$ & TIC/TOC \\
\hline $\mathrm{Cl}$ & $* *$ & $\mathrm{X}$ & $\mathrm{IC}$ \\
\hline $\mathrm{F}$ & $* *$ & $X$ & IC \\
\hline NO3 & $* *$ & $\mathrm{X}$ & IC \\
\hline $\mathrm{SO} 4$ & $* *$ & $X$ & IC \\
\hline PO4 & $* *$ & $X$ & IC \\
\hline As & $*$ & $\mathrm{~N} / \mathrm{A}$ & AA \\
\hline $\mathrm{Se}$ & $*$ & $\mathrm{~N} / \mathrm{A}$ & AA \\
\hline
\end{tabular}


Personnel performed rheological measurements with a RV30/m5 rotoviscometer. They performed the measurements at $25^{\circ} \mathrm{C}$ with an $\mathrm{NV}$ double concentric rotor and cylinder. The rotor ramped from $0-2700 \mathrm{sec}^{-1}$ shear rate in five minutes, held the $2700 \mathrm{sec}^{-1}$ shear rate for one minute, and ramped from $2700-0 \mathrm{sec}^{-1}$ in five minutes. Each sample was measured at least two times.

The filtrate and unwashed slurry data was fit with the following rheological model

$$
\tau=\mu \gamma / 1000
$$

where $\tau$ is the shear stress (in Pascals), $\mu$ is the Newtonian viscosity (in centipoises), and $\gamma$ is the shear rate $\left(\mathrm{in} \mathrm{sec}^{-1}\right)$. The slope of shear stress versus shear rate yields the viscosity (in Pascal second). The factor of 1000 converts Pascal seconds to centipoise.

The data from the concentrated and washed slurry was fit with a Bingham plastic model described by the following equation

$$
\tau=\tau_{\mathrm{y}}+\eta \gamma / 1000
$$

where $\tau_{\mathrm{y}}$ is the yield stress (in Pascal) and $\eta$ is the consistency or infinite viscosity (in centipoises).

The total solids (both insoluble solids and soluble salts) were measured by heating at $115+/-5^{\circ} \mathrm{C}$ until a constant dry weight was achieved. The samples were dried at $115^{\circ} \mathrm{C}$ rather than $105^{\circ} \mathrm{C}$ listed in the Test Specification because we have observed that this temperature is better for achieving a stable dry weight for samples with high dissolved salt content.

The weight $\%$ insoluble solids and weight $\%$ soluble solids were calculated after measuring the weight $\%$ total solids in the slurry and the weight $\%$ soluble solids in a filtered portion of the supernatant. This technique is used for determining the weight $\%$ insoluble solids rather than collecting and measuring the insoluble solids directly for two reasons: (1) it is less prone to experimental errors; and (2) it includes the water-soluble salts that would be dissolved during the water rinse of the solids to remove interstitial supernatant. The expression used for calculating the insoluble solids is:

$$
\mathrm{IS}=\mathrm{TS}-(100-\mathrm{TS}) \quad \mathrm{x} \frac{(\mathrm{FS} / 100)}{(1-\mathrm{FS} / 100)}
$$

where

IS $=$ weight $\%$ insoluble solids in the slurry

$\mathrm{TS}=$ weight $\%$ total solids in the slurry

$\mathrm{FS}=$ weight $\%$ soluble solids in the filtered supernatant 
The weight $\%$ soluble solids in the as-received slurry (SS) was then calculated from the difference in measured total weight \% solids in the slurry (TS) and the calculated weight \% insoluble solids (IS):

$\mathrm{SS}=\mathrm{TS}-\mathrm{IS}$

Density measurements were performed by weighing a known volume of sample.

Slurry samples were collected, dried and then submitted for particle size analysis by scanning electron microscope (SEM). The Analytical Development Section performed the SEM analysis and provided SEM pictures to the authors which are shown in Appendix D. The analysis was performed at 41X, 333X, 2300X, and 4600X. Personnel measured the size of particles on each of the pictures.

Filtrate samples were dissolved prior to analysis to ensure that all components were soluble. The dissolution was performed by mixing $5 \mathrm{~mL}$ of sample, $5 \mathrm{~mL}$ of nitric acid, and $2 \mathrm{~mL}$ of hydrogen peroxide. The samples were capped, mixed, and heated to $115^{\circ} \mathrm{C}$ for two hours. After heating, the samples were cooled and diluted to $100 \mathrm{~mL}$ with deionized water. This procedure can be found in laboratory notebook WSRC-NB-2003-00031.

Acid digestion of the final solids slurry was performed as follows. Personnel mixed between 0.5 and 1 grams of the slurry, $3 \mathrm{~mL}$ of nitric acid, $9 \mathrm{~mL}$ of $\mathrm{HCl}$, and $5 \mathrm{~mL}$ of $\mathrm{HF}$ in a Teflon pressure vessel. The vessel was capped, mixed, and placed into a $115^{\circ} \mathrm{C}$ oven for three hours. After three hours, the vessel was removed from the oven, allowed to cool, and the contents diluted to $1000 \mathrm{~mL}$ with $0.6 \mathrm{M}$ boric acid. This procedure can be found in laboratory notebook WSRC-NB-2003-00031.

Water leaching of the solids was performed so TIC/TOC and anion analyses could be performed. About $115 \mathrm{~mL}$ of slurry from the CUF was split up among 3 centrifuge tubes and centrifuged at high speed for over an hour. All liquid was poured off; then the wet solids were weighed. Twenty five $\mathrm{mL}$ of deionized water was added to the solids in each centrifuge tube. After vigorously shaking the tubes, they were placed in an oven at $115^{\circ} \mathrm{C}$ for three hours. After cooling, the water/solids solutions were diluted to about $40 \mathrm{~mL}$ including rinses of the centrifuge tubes. This procedure can be found in laboratory notebook WSRC-NB2003-00031.

\subsection{RESULTS}

The test specification ${ }^{1}$ calls for target minimum reportable quantities (MRQs) for analytes as listed in Appendix C. The MRQ is defined in this test specification as the reporting value that is at least 3 times above the Minimum Detection Limit (Activity). SRTC did not meet the MRQs of eleven analytes from the final washed slurry sample and two analytes, Sr and Am-241, from the filtrate analyses, so SRTC personnel contacted the BNI R\&T representative to discuss the impact. Since there was such a low solids content in the slurry, per BNI R\&T, SRTC did not repeat these analyses. 


\subsubsection{Filtration Test Results}

Table 2-3 shows the clean water flux and strontium carbonate flux data. In previous tests with the radioactive CUF and a 0.1 micron filter, the clean water flux at 20 psi measured 0.5 $-1.0 \mathrm{gpm} / \mathrm{ft} 2{ }^{4,5,6}$ Since one measured clean water flux at $20 \mathrm{psi}$ was $0.56 \mathrm{gpm} / \mathrm{ft} 2$, the filter was considered clean and the testing begun.

Table 2-3 Clean Water and Strontium Carbonate Flux

\begin{tabular}{|c|c|c|c|c|}
\hline Feed & $\underline{\text { Temperature }\left({ }^{\circ} \mathrm{C}\right)}$ & $\underline{\text { Axial velocity (ft/s) }}$ & $\underline{\text { TMP (psi) }}$ & $\begin{array}{c}\text { Flux } \\
\left(\text { gpm/ft2)@2.25 }{ }^{\circ} \mathrm{C}\right.\end{array}$ \\
\hline Water & 20.7 & 11.0 & 10 & 0.34 \\
\hline Water & 20.7 & 11.0 & 20 & 0.63 \\
\hline $\mathrm{SrCO} 3$ & 21.0 & 11.1 & 10 & 0.25 \\
\hline $\mathrm{SrCO} 3$ & 22.4 & 11.0 & 20 & 0.44 \\
\hline $\mathrm{SrCO} 3$ & 23.0 & 11.2 & 30 & 0.62 \\
\hline Water & 25.0 & 11.1 & 20 & 0.31 \\
\hline
\end{tabular}

Figure 2-3 and Table A- 2 show the filter flux during dewatering. The average measured flux of $0.085 \mathrm{gpm} / \mathrm{ft}^{2}$ exceeds the target of $0.03 \mathrm{gpm} / \mathrm{ft}^{2}$.

Dewatering Flux @25 C

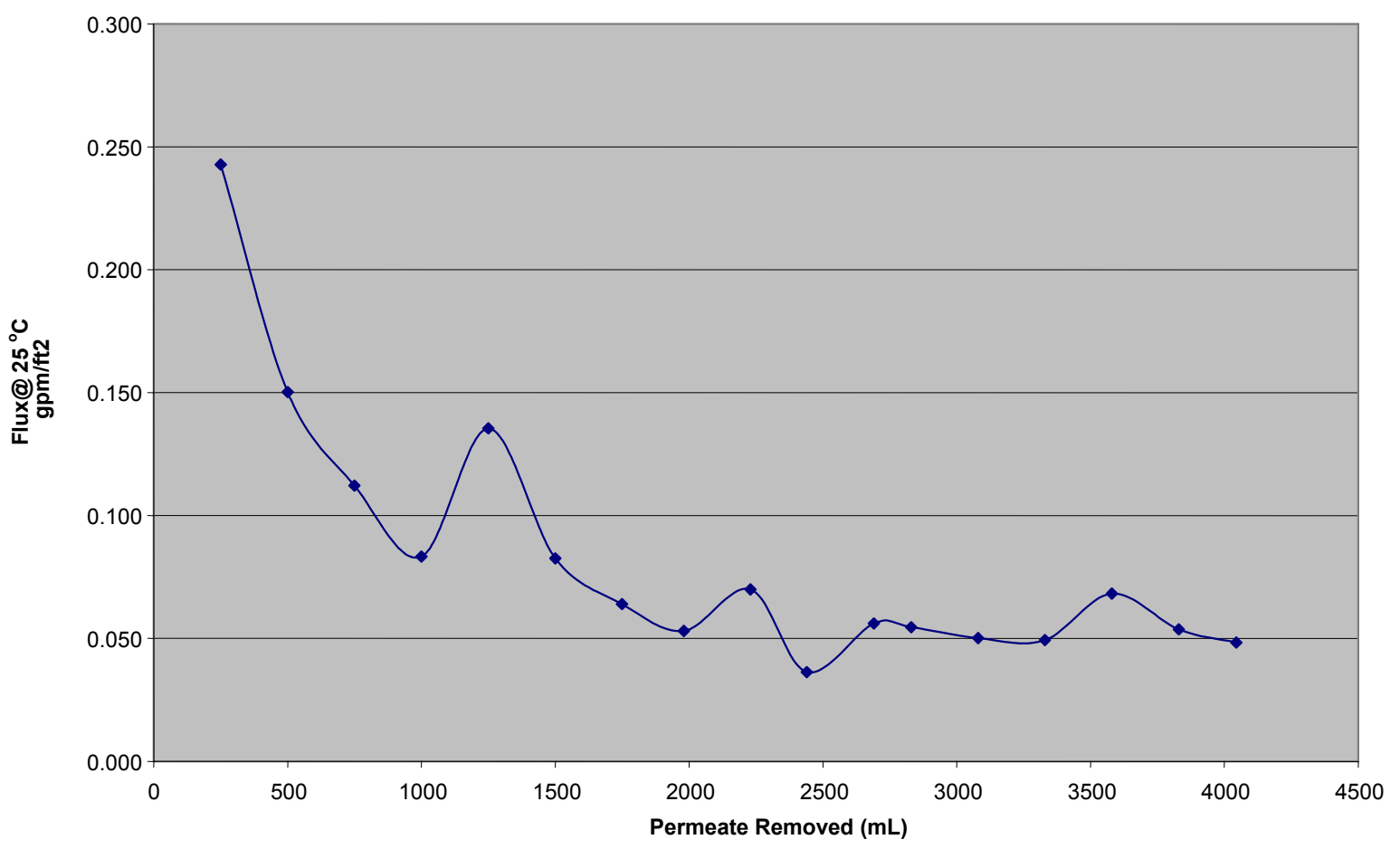

Figure 2-3 Filter Flux During Dewatering 
Figure 2-4, Figure 2-5, and Table A- 1 show the filter flux during the matrix tests performed at 0.9 wt. $\%$ insoluble solids. In all cases, the filter flux is less than $0.03 \mathrm{gpm} / \mathrm{ft}^{2}$. There is a correlation between transmembrane pressure and filter flux per the statistical analysis shown in Appendix B. There is no observed correlation between axial velocity and filter flux.

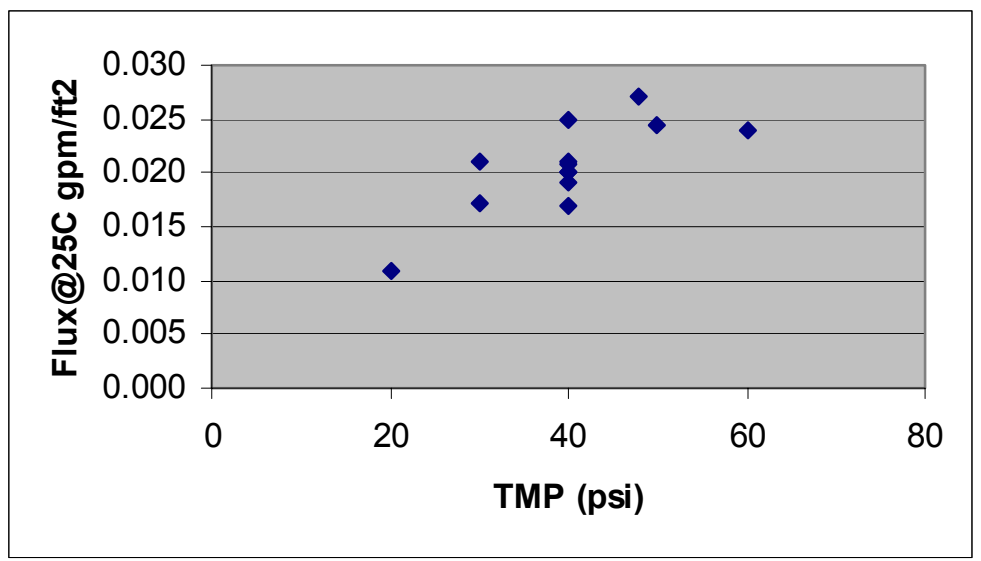

Figure 2-4 Filter Flux of 0.9 wt.\% AN-104 Slurry

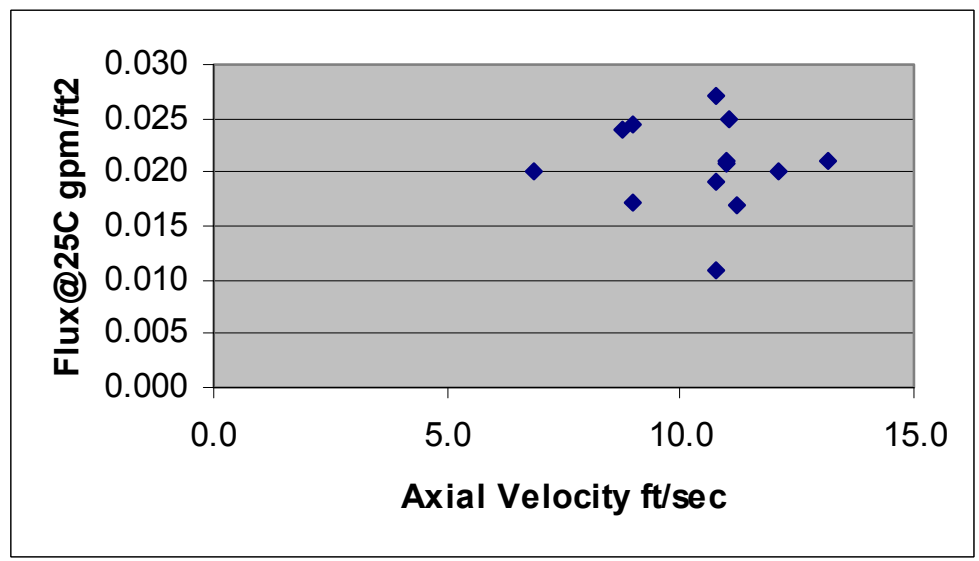

Figure 2-5 Filter Flux of 0.9 wt.\% AN 104 Slurry 


\subsubsection{Washing Results}

Table 2-4 shows the sodium and Cs-137 concentration in supernate samples collected during the washing. The sodium concentration in the supernate decreases fairly linearly throughout the washes as expected. The Na results vary widely in Table 2-5 between the AA and the ICPES methods for determining it. The Na value of $12,300,000 \mu \mathrm{g} / \mathrm{mL}$ as determined by AA is incorrect. The Cs-137 decreases steadily as expected.

Table 2-4 Washing Sample Results

\begin{tabular}{|c|c|c|}
\hline Sample & $\frac{\mathbf{N a}}{(\mu \mathrm{g} / \mathbf{m} L)}$ & Cs-137 $\mu \mathrm{Ci} / \mathrm{g}$ \\
\hline Wash 1 & $106,000$. & $2.85 \mathrm{E}+02$ \\
\hline Wash 2 & $100,000$. & \\
\hline Wash 3 & $90,100$. & \\
\hline Wash 4 & 82,100 . & $1.78 \mathrm{E}+02$ \\
\hline Wash 5 & 75,900 . & \\
\hline Wash 6 & 68,200 . & \\
\hline Wash 7 & 60,000 . & \\
\hline Wash 8 & 55,300 . & $1.13 \mathrm{E}+02$ \\
\hline Wash 9 & 50,000 . & \\
\hline Wash 10 & 47,000 . & \\
\hline Wash 11 & & \\
\hline Wash 12 & 41200. & $9.32 \mathrm{E}+01$ \\
\hline
\end{tabular}


Table 2-5 shows the composition of the wash solution 12 . Wash solution 12 is the only wash that had the full suite of analyses performed on it. The units are per $\mathrm{mL}$ of wash solution.

Table 2-5 Washing Sample Results of Wash 12

\begin{tabular}{|c|c|c|c|}
\hline $\mathbf{K}$ & $\mu \mathrm{g} / \mathrm{mL}$ & 875 & $\begin{array}{l}\% \\
\text { Uncertainty }\end{array}$ \\
\hline Na-AA & $\mu \mathrm{g} / \mathrm{mL}$ & $12,300,000$ & \\
\hline Na-ICPES & $\begin{array}{c}\text { conc, } \\
\mu \mathrm{g} / \mathrm{mL}\end{array}$ & 41200 & \\
\hline Cs-137 & $\mu \mathrm{Ci} / \mathrm{mL}$ & $1.17 \mathrm{E}+02$ & 2.4 \\
\hline Co-60 & $\mu \mathrm{Ci} / \mathrm{mL}$ & $1.20 \mathrm{E}-04$ & 2.49 \\
\hline Eu-154 & $\mu \mathrm{Ci} / \mathrm{mL}$ & $6.30 \mathrm{E}-05$ & 6.77 \\
\hline Eu-155 & $\mu \mathrm{Ci} / \mathrm{mL}$ & $3.45 \mathrm{E}-05$ & mda \\
\hline Am-241 & $\mu \mathrm{Ci} / \mathrm{mL}$ & $1.62 \mathrm{E}-04$ & 5.92 \\
\hline Gross Alpha & $\mu \mathrm{Ci} / \mathrm{mL}$ & $1.10 \mathrm{E}-03$ & 15 \\
\hline $\mathrm{Hg}$ & $\mu \mathrm{g} / \mathrm{mL}$ & $<0.110$ & \\
\hline BROMIDE & $\mu \mathrm{g} / \mathrm{mL}$ & $<100$ & \\
\hline CHLORIDE & $\mu \mathrm{g} / \mathrm{mL}$ & 1060 & \\
\hline FLUORIDE & $\mu \mathrm{g} / \mathrm{mL}$ & $<20$ & \\
\hline FORMATE & $\mu \mathrm{g} / \mathrm{mL}$ & 183 & \\
\hline NITRATE & $\mu \mathrm{g} / \mathrm{mL}$ & 23200 & \\
\hline NITRITE & $\mu \mathrm{g} / \mathrm{mL}$ & 14300 & \\
\hline OXALATE & $\mu \mathrm{g} / \mathrm{mL}$ & 1040 & \\
\hline PHOSPHATE & $\mu \mathrm{g} / \mathrm{mL}$ & $<100$ & \\
\hline SULFATE & $\mu \mathrm{g} / \mathrm{mL}$ & 960 & \\
\hline PU-238 & $\mu \mathrm{Ci} / \mathrm{mL}$ & $2.25 \mathrm{E}-04$ & 38.9 \\
\hline PU-239/240 & $\mu \mathrm{Ci} / \mathrm{mL}$ & $7.34 \mathrm{E}-05$ & 35.38 \\
\hline Beta & $\mu \mathrm{Ci} / \mathrm{mL}$ & $1.39 \mathrm{E}+02$ & 20 \\
\hline SR-90 & $\mu \mathrm{Ci} / \mathbf{m L}$ & $2.13 \mathrm{E}-01$ & 12.4 \\
\hline TC-99 & $\mu \mathrm{Ci} / \mathrm{mL}$ & $3.17 \mathrm{E}-02$ & 5.5 \\
\hline TIC & $\mu \mathrm{g} / \mathrm{mL}$ & 1740 & \\
\hline TOC & $\mu \mathrm{g} / \mathrm{mL}$ & 800 & \\
\hline TC & $\mu \mathrm{g} / \mathrm{mL}$ & 2540 & \\
\hline
\end{tabular}




\subsubsection{Analytical Results}

\subsubsection{Particle Size Data}

Table 2-6 shows the results and Appendix D shows the actual pictures. The results shown are from the same sample, using different magnification and examining different fractions of the sample. The mean particle size varies widely, depending on the magnification of the SEM. In reviewing the pictures, the authors observed that at low magnification, the particles were extremely small. They had difficulty determining the location of the edges of the particles and therefore, determining their size. At magnification $2300 \mathrm{X}$ and larger, the mean particle size is approximately the same. The authors recommend using a mean particle size of $0.8-1.7$ micron for the AN-104 sample.

Table 2-6 Particle Size of AN-104 Solids

\begin{tabular}{|l|c|c|c|c|c|}
\hline \multicolumn{1}{|c|}{ Sample ID } & $\begin{array}{c}\text { \# of } \\
\text { particles }\end{array}$ & Avg. D, $\boldsymbol{\mu}$ & Std Dev, $\boldsymbol{\mu}$ & Max. D, $\boldsymbol{\mu}$ & Min. D, $\boldsymbol{\mu}$ \\
\hline 3-191232-10X-SE & 61 & 4.8 & 1.5 & 9.4 & 2.4 \\
\hline 3-193822-41X-SE & 23 & 38 & 11 & 60 & 20 \\
\hline 3-193282-41X-BS & 26 & 39 & 11 & 67 & 19 \\
\hline 3-193822-333X-BS & 52 & 13 & 6 & 31 & 4 \\
\hline 3-193822-2300X-SE & 37 & 1.5 & 0.4 & 2.4 & 1.0 \\
\hline 3-193822-2300X-BS & 60 & 1.7 & 0.7 & 5.7 & 0.7 \\
\hline 3-193822-4600X-SE & 44 & 0.77 & 0.21 & 1.5 & 0.36 \\
\hline 3-193822-4600-BS & 59 & 1.29 & 0.30 & 2.18 & 0.73 \\
\hline
\end{tabular}

\subsubsection{Filtrate Data}

The filtrate was visually inspected for solids and none were observed. Table 2-7 shows the composition of filtrate samples collected at the start of the dewatering process. The units are per $\mathrm{mL}$ of filtrate. Table 2-8 shows the anion data for both the filtrate after concentration and the filtrate at the end of washing. 
WSRC-TR-2003-00295, REV. 0 SRT-RPP-2003-00137, REV. 0

Table 2-7 Chemical Composition of Filtrate Samples

\begin{tabular}{|c|c|c|c|c|}
\hline LIMS & & 300194279 & 300194280 & 300194281 \\
\hline Sample ID & & Filtrate 1 & Filtrate 2 & Filtrate 3 \\
\hline \multicolumn{5}{|l|}{ ICPES } \\
\hline $\mathrm{Ag}$ & $\mu \mathrm{g} / \mathrm{mL}$ & $<1.95$ & $<1.94$ & $<1.65$ \\
\hline $\mathrm{Al}$ & $\mu \mathrm{g} / \mathrm{mL}$ & 16128 & 13734 & 13734 \\
\hline $\mathrm{B}$ & $\mu \mathrm{g} / \mathrm{mL}$ & 35.2 & 20.7 & 24.1 \\
\hline $\mathrm{Ba}$ & $\mu \mathrm{g} / \mathrm{mL}$ & $<4.63$ & $<4.61$ & $<3.91$ \\
\hline $\mathrm{Ca}$ & $\mu \mathrm{g} / \mathrm{mL}$ & $<5.60$ & $<5.58$ & $<4.75$ \\
\hline $\mathrm{Cd}$ & $\mu \mathrm{g} / \mathrm{mL}$ & $<1.02$ & $<1.01$ & $<0.866$ \\
\hline $\mathrm{Ce}$ & $\mu \mathrm{g} / \mathrm{mL}$ & 13.5 & $<6.5$ & $<5.56$ \\
\hline $\mathrm{Cr}$ & $\mu \mathrm{g} / \mathrm{mL}$ & 180 & 150 & 150 \\
\hline $\mathrm{Cu}$ & $\mu \mathrm{g} / \mathrm{mL}$ & 2.22 & 1.63 & 1.15 \\
\hline $\mathrm{Fe}$ & $\mu \mathrm{g} / \mathrm{mL}$ & $<0.488$ & $<0.486$ & 0.818 \\
\hline $\mathrm{Gd}$ & $\mu \mathrm{g} / \mathrm{mL}$ & $<5.71$ & $<5.68$ & $<4.83$ \\
\hline $\mathrm{La}$ & $\mu \mathrm{g} / \mathrm{mL}$ & 2.12 & $<1.75$ & 1.68 \\
\hline $\mathrm{Li}$ & $\mu \mathrm{g} / \mathrm{mL}$ & $<10.5$ & $<10.4$ & $<8.88$ \\
\hline $\mathrm{Mg}$ & $\mu \mathrm{g} / \mathrm{mL}$ & $<1.30$ & $<1.29$ & $<1.09$ \\
\hline $\mathrm{Mn}$ & $\mu \mathrm{g} / \mathrm{mL}$ & $<0.195$ & $<0.194$ & $<0.165$ \\
\hline Mo & $\mu \mathrm{g} / \mathrm{mL}$ & 61.7 & 38.2 & 40.4 \\
\hline $\mathrm{Na}$ & $\mu \mathrm{g} / \mathrm{mL}$ & 139000 & 117000 & 116000 \\
\hline $\mathrm{Ni}$ & $\mu \mathrm{g} / \mathrm{mL}$ & $<3.29$ & $<3.28$ & $<2.78$ \\
\hline $\mathrm{P}$ & $\mu \mathrm{g} / \mathrm{mL}$ & 562 & 498 & 462 \\
\hline $\mathrm{Pb}$ & $\mu \mathrm{g} / \mathrm{mL}$ & 14.2 & 13.2 & 11.0 \\
\hline $\mathrm{S}$ & $\mu \mathrm{g} / \mathrm{mL}$ & 1575 & 1298 & 1323 \\
\hline $\mathrm{Sb}$ & $\mu \mathrm{g} / \mathrm{mL}$ & $<92.1$ & $<91.7$ & $<78.0$ \\
\hline $\mathrm{Si}$ & $\mu \mathrm{g} / \mathrm{mL}$ & 105 & 92.5 & 90.6 \\
\hline $\mathrm{Sn}$ & $\mu \mathrm{g} / \mathrm{mL}$ & 62.2 & 35.0 & 39.9 \\
\hline $\mathrm{Sr}$ & $\mu \mathrm{g} / \mathrm{mL}$ & $<1.85$ & $<1.84$ & $<1.57$ \\
\hline $\mathrm{Ti}$ & $\mu \mathrm{g} / \mathrm{mL}$ & $<1.88$ & $<1.86$ & $<1.59$ \\
\hline $\mathrm{U}$ & $\mu \mathrm{g} / \mathrm{mL}$ & 61.9 & $<55.0$ & $<46.9$ \\
\hline $\mathrm{Zn}$ & $\mu \mathrm{g} / \mathrm{mL}$ & 3.23 & 2.62 & 2.82 \\
\hline $\mathrm{Zr}$ & $\mu \mathrm{g} / \mathrm{mL}$ & $<5.56$ & $<5.53$ & $<4.71$ \\
\hline \multicolumn{5}{|l|}{$\mathbf{A A}$} \\
\hline K & $\mu \mathrm{g} / \mathrm{mL}$ & 2646 & 2054 & 2079 \\
\hline $\mathrm{Na}$ & $\mu \mathrm{g} / \mathrm{mL}$ & 197820 & 92988 & 101052 \\
\hline \multicolumn{5}{|l|}{ PUTTA } \\
\hline $\mathrm{Pu} 238$ & $\mu \mathrm{Ci} / \mathrm{mL}$ & $3.60 \mathrm{E}-04$ & $3.81 \mathrm{E}-04$ & $5.57 \mathrm{E}-04$ \\
\hline$\%$ Uncertainty & & 40.92 & 40.09 & 17.82 \\
\hline \multirow[t]{2}{*}{$\mathrm{Pu} 239 / 240$} & $\mu \mathrm{Ci} / \mathrm{mL}$ & $<1.02 \mathrm{E}-04$ & $<8.63 \mathrm{E}-05$ & $3.01 \mathrm{E}-04$ \\
\hline & & MDA & MDA & 36.06 \\
\hline
\end{tabular}


WSRC-TR-2003-00295, REV. 0 SRT-RPP-2003-00137, REV. 0

\begin{tabular}{|c|c|c|c|c|}
\hline LIMS & & 300194279 & 300194280 & 300194281 \\
\hline Sample ID & & Filtrate 1 & Filtrate 2 & Filtrate 3 \\
\hline \multicolumn{5}{|l|}{ RAD screen } \\
\hline alpha count & $\mu \mathrm{Ci} / \mathrm{mL}$ & $1.33 \mathrm{E}-01$ & $1.30 \mathrm{E}-01$ & $1.31 \mathrm{E}-01$ \\
\hline$\%$ Uncertainty & & 7 & 7 & 7 \\
\hline beta count & $\mu \mathrm{Ci} / \mathrm{mL}$ & $3.24 \mathrm{E}+02$ & $2.72 \mathrm{E}+02$ & $2.70 \mathrm{E}+02$ \\
\hline$\%$ Uncertainty & & 15 & 15 & 15 \\
\hline $\begin{array}{l}\text { Sr90 beta liq } \\
\text { sint }\end{array}$ & $\mu \mathrm{Ci} / \mathrm{mL}$ & $9.25 \mathrm{E}-02$ & $1.06 \mathrm{E}-01$ & $8.80 \mathrm{E}-02$ \\
\hline$\%$ Uncertainty & & 9.9 & 9.6 & 9.7 \\
\hline $\begin{array}{c}\text { Tc99 beta liq } \\
\text { scnt }\end{array}$ & $\mu \mathrm{Ci} / \mathrm{mL}$ & $1.02 \mathrm{E}-01$ & $9.14 \mathrm{E}-02$ & 8.23E-02 \\
\hline$\%$ Uncertainty & & 6.2 & 6.3 & 5.8 \\
\hline Cs- 137 & $\mu \mathrm{Ci} / \mathrm{mL}$ & $2.67 \mathrm{E}+02$ & $2.28 \mathrm{E}+02$ & $2.24 \mathrm{E}+02$ \\
\hline$\%$ Uncertainty & & $150.00 \%$ & 1.6 & 1.5 \\
\hline $\mathrm{Co}$ & $\mu \mathrm{g} / \mathrm{mL}$ & $1.26 \mathrm{E}-01$ & $1.26 \mathrm{E}-01$ & $1.26 \mathrm{E}-01$ \\
\hline Mo & $\mu \mathrm{g} / \mathrm{mL}$ & $3.40 \mathrm{E}+01$ & $2.99 \mathrm{E}+01$ & $3.02 \mathrm{E}+01$ \\
\hline Am-241 & $\mu \mathrm{Ci} / \mathrm{mL}$ & $<1.80 \mathrm{E}-03$ & $<1.44 \mathrm{E}-03$ & $<1.62 \mathrm{E}-03$ \\
\hline $\mathrm{Co}-60$ & $\mu \mathrm{Ci} / \mathrm{mL}$ & $3.02 \mathrm{E}-04$ & $2.95 \mathrm{E}-04$ & $2.82 \mathrm{E}-04$ \\
\hline$\%$ Uncertainty & & 9 & 3.6 & 7.9 \\
\hline Eu-154 & $\mu \mathrm{Ci} / \mathrm{mL}$ & $5.11 \mathrm{E}-03$ & $4.40 \mathrm{E}-03$ & $4.43 \mathrm{E}-03$ \\
\hline$\%$ Uncertainty & & 1.4 & 1.6 & 1.3 \\
\hline Eu-155 & $\mu \mathrm{Ci} / \mathrm{mL}$ & $4.81 \mathrm{E}-04$ & $4.45 \mathrm{E}-04$ & $3.60 \mathrm{E}-04$ \\
\hline$\%$ Uncertainty & & 21.6 & 11.1 & 26.4 \\
\hline U-235 & $\mu \mathrm{g} / \mathrm{mL}$ & $5.04 \mathrm{E}-02$ & $5.04 \mathrm{E}-02$ & $3.78 \mathrm{E}-02$ \\
\hline U-238 & $\mu \mathrm{g} / \mathrm{mL}$ & $8.19 \mathrm{E}+00$ & $6.93 \mathrm{E}+00$ & $7.06 \mathrm{E}+00$ \\
\hline
\end{tabular}


WSRC-TR-2003-00295, REV. 0

SRT-RPP-2003-00137, REV. 0

Table 2-8 Filtrate vs. Washed Filtrate Anion-Organic Data

\begin{tabular}{|c|c|c|c|c|}
\hline Anion & Units & $\begin{array}{c}\text { Unwashed } \\
\text { Filtrate }\end{array}$ & $\begin{array}{c}\text { Washed } \\
\text { Filtrate }\end{array}$ & Wash Factors \\
\hline $\mathrm{F}$ & $\mu \mathrm{g} / \mathrm{ml}$ & 66 & 46 & 0.70 \\
\hline $\mathrm{Cl}$ & $\mu \mathrm{g} / \mathrm{ml}$ & 3170 & 1100 & 0.35 \\
\hline $\mathrm{NO} 2$ & $\mu \mathrm{g} / \mathrm{ml}$ & 43300 & 14000 & 0.32 \\
\hline $\mathrm{NO} 3$ & $\mu \mathrm{g} / \mathrm{ml}$ & 75300 & 21800 & 0.29 \\
\hline $\mathrm{PO} 4$ & $\mu \mathrm{g} / \mathrm{ml}$ & 1490 & 195 & 0.13 \\
\hline $\mathrm{SO} 4$ & $\mu \mathrm{g} / \mathrm{ml}$ & 3810 & 1050 & 0.28 \\
\hline $\mathrm{TC}$ & $\mu \mathrm{g} / \mathrm{ml}$ & 6040 & 2760 & 0.46 \\
\hline $\mathrm{TIC}$ & $\mu \mathrm{g} / \mathrm{ml}$ & 3330 & 1620 & 0.49 \\
\hline $\mathrm{TOC}$ & $\mu \mathrm{g} / \mathrm{ml}$ & 2710 & 1140 & 0.42 \\
\hline
\end{tabular}

\subsubsection{Unwashed Solids Data}

Table 2-9 shows the composition of final 0.9 wt.\% insoluble solids slurry samples collected and prepared by water leaching. The units are per gram of wet solids after centrifugation and decantation.

Table 2-9 Chemical Composition of Unwashed Solids Sample by Water Leach

\begin{tabular}{|l|r|r|r|r|}
\hline \multicolumn{1}{|c|}{ LIMS ID } & & $\mathbf{3 0 0 1 9 5 3 7 7}$ & $\mathbf{3 0 0 1 9 5 3 7 8}$ & $\mathbf{3 0 0 1 9 5 3 7 9}$ \\
\hline \multicolumn{1}{|c|}{ Unser Sample ID } & & Leachate 1 & Leachate 2 & Leachate 3 \\
\hline \multicolumn{1}{|c|}{ ICA } & & & & \\
\hline FLUORIDE & $\mu \mathrm{g} / \mathrm{g}$ & $6.68 \mathrm{E}+01$ & $9.04 \mathrm{E}+01$ & $6.24 \mathrm{E}+01$ \\
\hline FORMATE & $\mu \mathrm{g} / \mathrm{g}$ & $4.34 \mathrm{E}+02$ & $4.52 \mathrm{E}+02$ & $4.68 \mathrm{E}+02$ \\
\hline NITRITE & $\mu \mathrm{g} / \mathrm{g}$ & $2.48 \mathrm{E}+04$ & $2.46 \mathrm{E}+04$ & $2.80 \mathrm{E}+04$ \\
\hline CHLORIDE & $\mu \mathrm{g} / \mathrm{g}$ & $2.07 \mathrm{E}+03$ & $1.81 \mathrm{E}+03$ & $2.03 \mathrm{E}+03$ \\
\hline OXALATE & $\mu \mathrm{g} / \mathrm{g}$ & $2.91 \mathrm{E}+04$ & $4.61 \mathrm{E}+04$ & $2.79 \mathrm{E}+04$ \\
\hline SULFATE & $\mu \mathrm{g} / \mathrm{g}$ & $1.90 \mathrm{E}+03$ & $1.72 \mathrm{E}+03$ & $1.87 \mathrm{E}+03$ \\
\hline PHOSPHATE & $\mu \mathrm{g} / \mathrm{g}$ & $<334$ & $<452$ & $<311$ \\
\hline NITRATE & $\mu \mathrm{g} / \mathrm{g}$ & $4.24 \mathrm{E}+04$ & $4.57 \mathrm{E}+04$ & $4.61 \mathrm{E}+04$ \\
\hline \multicolumn{1}{|c|}{ TIC/TOC } & & & & \\
\hline $\begin{array}{l}\text { Total Inorganic } \\
\text { Carbon }\end{array}$ & $\mu \mathrm{g} / \mathrm{g}$ & $2.64 \mathrm{E}+03$ & $2.83 \mathrm{E}+03$ & $2.38 \mathrm{E}+03$ \\
\hline $\begin{array}{l}\text { Total Organic } \\
\text { Carbon }\end{array}$ & $\mu \mathrm{g} / \mathrm{g}$ & $1.03 \mathrm{E}+04$ & $1.46 \mathrm{E}+04$ & $1.00 \mathrm{E}+04$ \\
\hline Total Carbon & $\mu \mathrm{g} / \mathrm{g}$ & $1.29 \mathrm{E}+04$ & $1.74 \mathrm{E}+04$ & $1.24 \mathrm{E}+04$ \\
\hline
\end{tabular}




\subsubsection{Concentrated, Washed Slurry Data}

Table 2-10 shows the composition of final solids slurry samples collected and prepared by acid digestion. The units are per gram of dried total solids. The high variability observed between samples is probably due to the large dilution of a small amount of solids. 
WSRC-TR-2003-00295, REV. 0 SRT-RPP-2003-00137, REV. 0

Table 2-10 Chemical Composition of Final Solids Sample by Acid Digestion

\begin{tabular}{|c|c|c|c|c|}
\hline LIMS \# & & 300193853 & 300193854 & 300193855 \\
\hline Sample Name & & WSLURY-1 & WSLURY-2 & WSLURY-3 \\
\hline \multicolumn{5}{|l|}{ ICPES } \\
\hline $\mathrm{Ag}$ & $\mu \mathrm{g} / \mathrm{g}$ & $<465$ & $<397$ & $<360$ \\
\hline $\mathrm{Al}$ & $\mu \mathrm{g} / \mathrm{g}$ & 24107 & 22441 & 49983 \\
\hline $\mathrm{Ba}$ & $\mu \mathrm{g} / \mathrm{g}$ & $<1105$ & $<942$ & $<853$ \\
\hline $\mathrm{Ca}$ & $\mu \mathrm{g} / \mathrm{g}$ & $<1340$ & 1234 & 4658 \\
\hline $\mathrm{Cd}$ & $\mu \mathrm{g} / \mathrm{g}$ & $<244$ & $<208$ & $<189$ \\
\hline $\mathrm{Ce}$ & $\mu \mathrm{g} / \mathrm{g}$ & $<1571$ & $<1340$ & $<1214$ \\
\hline $\mathrm{Cr}$ & $\mu \mathrm{g} / \mathrm{g}$ & 19177 & 15879 & 34682 \\
\hline $\mathrm{Cu}$ & $\mu \mathrm{g} / \mathrm{g}$ & 322.7 & 203.0 & 346.8 \\
\hline $\mathrm{Fe}$ & $\mu \mathrm{g} / \mathrm{g}$ & 1741 & 955 & 3104 \\
\hline $\mathrm{La}$ & $\mu \mathrm{g} / \mathrm{g}$ & $<418$ & $<357$ & $<324$ \\
\hline $\mathrm{Li}$ & $\mu \mathrm{g} / \mathrm{g}$ & $<2503$ & $<2132$ & $<1935$ \\
\hline $\mathrm{Mg}$ & $\mu \mathrm{g} / \mathrm{g}$ & $<309$ & $<263$ & $<238$ \\
\hline $\mathrm{Mn}$ & $\mu \mathrm{g} / \mathrm{g}$ & $<46.6$ & $<39.8$ & $<36.0$ \\
\hline Mo & $\mu \mathrm{g} / \mathrm{g}$ & $<3087$ & $<2628$ & $<2384$ \\
\hline $\mathrm{Na}$ & $\mu \mathrm{g} / \mathrm{g}$ & 138728 & 127508 & 267936 \\
\hline $\mathrm{Ni}$ & $\mu \mathrm{g} / \mathrm{g}$ & $<785$ & $<670$ & $<609$ \\
\hline $\mathrm{P}$ & $\mu \mathrm{g} / \mathrm{g}$ & $<4012$ & $<3434$ & 4318 \\
\hline $\mathrm{Pb}$ & $\mu \mathrm{g} / \mathrm{g}$ & $<1857$ & $<1581$ & 1731 \\
\hline $\mathrm{Si}$ & $\mu \mathrm{g} / \mathrm{g}$ & 16321 & 14111 & 22543 \\
\hline $\mathrm{Sn}$ & $\mu \mathrm{g} / \mathrm{g}$ & 82625 & 59164 & 57123 \\
\hline $\mathrm{Sr}$ & $\mu \mathrm{g} / \mathrm{g}$ & 1081 & 840 & 2265 \\
\hline $\mathrm{Ti}$ & $\mu \mathrm{g} / \mathrm{g}$ & $<449$ & $<381$ & $<347$ \\
\hline $\mathrm{U}$ & $\mu \mathrm{g} / \mathrm{g}$ & $<13230$ & $<11250$ & $<10200$ \\
\hline $\mathrm{V}$ & $\mu \mathrm{g} / \mathrm{g}$ & 751 & 513 & 401 \\
\hline $\mathrm{Zn}$ & $\mu \mathrm{g} / \mathrm{g}$ & 186.7 & 615.4 & 751.4 \\
\hline \multicolumn{5}{|l|}{$\mathbf{A A}$} \\
\hline As & $\mu \mathrm{g} / \mathrm{g}$ & $<291$ & $<248$ & $<225$ \\
\hline $\mathrm{K}$ & $\mu \mathrm{g} / \mathrm{g}$ & 3434 & 3434 & 5712 \\
\hline $\mathrm{Na}$ & $\mu \mathrm{g} / \mathrm{g}$ & 115607 & 109487 & 247535 \\
\hline $\mathrm{Se}$ & $\mu \mathrm{g} / \mathrm{g}$ & $<291$ & $<248$ & $<225$ \\
\hline $\mathrm{Hg}$ & $\mu \mathrm{g} / \mathrm{g}$ & $<639$ & $<544$ & $<496$ \\
\hline CS-137 & $\mu \mathbf{C i} / g$ & & & \\
\hline Am-241 & $\mu \mathrm{Ci} / \mathrm{g}$ & $5.33 \mathrm{E}-01$ & $3.11 \mathrm{E}-01$ & $5.67 \mathrm{E}-01$ \\
\hline Uncertainty, \% & & 7.75 & 18.68 & 6.38 \\
\hline PU-238 & $\mu \mathrm{Ci} / \mathrm{g}$ & $9.96 \mathrm{E}-02$ & $5.58 \mathrm{E}-02$ & $1.17 \mathrm{E}-01$ \\
\hline Uncertainty, \% & & 24.82 & 47.76 & 20 \\
\hline PU-239/240 & $\mu \mathbf{C i} / \mathbf{g}$ & 7.89E-02 & 4.89E-02 & $9.39 \mathrm{E}-02$ \\
\hline Uncertainty, \% & & 18.1 & 43.93 & 17.81 \\
\hline
\end{tabular}


WSRC-TR-2003-00295, REV. 0 SRT-RPP-2003-00137, REV. 0

\begin{tabular}{|c|c|c|c|c|}
\hline LIMS \# & & 300193853 & 300193854 & 300193855 \\
\hline Sample Name & & WSLURY-1 & WSLURY-2 & WSLURY-3 \\
\hline ALPHA COUNT & $\mu \mathrm{Ci} / \mathrm{g}$ & $5.74 \mathrm{E}+00$ & $5.58 \mathrm{E}+00$ & $7.83 \mathrm{E}+00$ \\
\hline Uncertainty, \% & & 20 & 20 & 20 \\
\hline BETA COUNT & $\mu \mathrm{Ci} / \mathrm{g}$ & $1.00 \mathrm{E}+03$ & $9.68 \mathrm{E}+02$ & $1.84 \mathrm{E}+03$ \\
\hline Uncertainty, \% & & 10 & 10 & 10 \\
\hline $\begin{array}{l}\text { SR90 BETA LIQ } \\
\text { SCINT }\end{array}$ & $\mu \mathrm{Ci} / \mathrm{g}$ & $2.40 \mathrm{E}+02$ & $1.99 \mathrm{E}+02$ & $3.78 \mathrm{E}+02$ \\
\hline Uncertainty, \% & & 10.1 & 10.8 & 10 \\
\hline $\begin{array}{l}\text { TC99 BETA LIQ } \\
\text { SCINT }\end{array}$ & $\mu \mathrm{Ci} / \mathrm{g}$ & $2.05 \mathrm{E}-01$ & 2.13E-01 & $3.05 \mathrm{E}-01$ \\
\hline Uncertainty, \% & & 15.1 & 12 & 8.9 \\
\hline $\mathrm{Co}$ & $\mu \mathrm{g} / \mathbf{l}$ & $3.85 \mathrm{E}+00$ & $2.93 \mathrm{E}+00$ & $5.75 \mathrm{E}+00$ \\
\hline Co-60 & $\mu \mathrm{Ci} / \mathrm{g}$ & $9.02 \mathrm{E}-02$ & $5.91 \mathrm{E}-02$ & $1.23 \mathrm{E}-01$ \\
\hline Uncertainty, \% & & 24.6 & 24.3 & 9.4 \\
\hline Eu-154 & $\mu \mathrm{Ci} / \mathrm{g}$ & $<9.76 \mathrm{E}-02$ & $<8.60 \mathrm{E}-02$ & 4.73E-01 \\
\hline Eu-155 & $\mu \mathrm{Ci} / \mathrm{g}$ & $<1.33 \mathrm{E}-01$ & $<1.12 \mathrm{E}-02$ & $2.04 \mathrm{E}-01$ \\
\hline
\end{tabular}

\subsubsection{Rheology}

Table 2-11 shows the rheology data ${ }^{8}$. The samples were both unwashed and washed filtrate and slurry. The filtrate viscosity is $3.5 \mathrm{cp}$. The slurry yield stress measured $1.5 \mathrm{~Pa}$, which is not very high and should not cause processing problems. However, because of the low volume of insoluble solids, personnel were unable to create a sample in sufficient quantity to even approach $15 \mathrm{wt} \%$ insoluble solids slurry. If the insoluble solids concentration had been higher, the yield stress would have been much higher.

Table 2-11 Rheology Data

\begin{tabular}{|l|c|c|}
\hline \multicolumn{1}{|c|}{ Sample ID (AN-104) } & Viscosity or Consistency (cP) & Yield Stress (Pa) \\
\hline CUF Filtrate & 3.5 & 0 \\
\hline CUF 0.4 wt\% Slurry & 3.85 & 0 \\
\hline CUF Washed Filtrate & 1.3 & 0 \\
\hline CUF Washed 2 wt\% Slurry & 1.9 & 1.47 \\
\hline
\end{tabular}




\subsubsection{Density and Solids Concentration}

Table 2-12 shows the density and solids data.

Table 2-12 Density and Solids Data

\begin{tabular}{|l|c|c|c|c|}
\hline \multicolumn{1}{|c|}{ Sample } & $\begin{array}{c}\text { Density } \\
\text { g/mL }\end{array}$ & $\begin{array}{c}\text { Total } \\
\text { Solids }\end{array}$ & $\begin{array}{c}\text { Insoluble } \\
\text { Solids }\end{array}$ & $\begin{array}{c}\text { Soluble } \\
\text { Solids }\end{array}$ \\
\hline Filtrate & 1.26 & $29.3 \mathrm{wt} \%$ & 0 & $29.3 \mathrm{wt} \%$ \\
\hline CUF Concentrated Slurry & N/A & $30.0 \mathrm{wt} \%$ & $0.9 \mathrm{wt} \%$ & $29.1 \mathrm{wt} \%$ \\
\hline 1:5 Decanted, Washed CUF Slurry & N/A & $11.6 \mathrm{wt} \%$ & $2.2 \mathrm{wt} \mathrm{\%}$ & $11.62 \mathrm{wt} \%$ \\
\hline Washed Slurry Supernate & N/A & $13.6 \mathrm{wt} \%$ & 0 & $13.6 \mathrm{wt} \%$ \\
\hline
\end{tabular}

\subsubsection{Filter Cleaning}

Table 2-13 shows the flux following filter cleaning. The axial velocity for all filter cleaning and flux testing is 11 feet per second. The filter was flushed four times with inhibited water initially. On the second, third, and fourth batch significant foaming was observed. The filter was then cleaned with five successive batches of $1 \mathrm{M}$ nitric acid, then two batches of $0.01 \mathrm{M}$ nitric acid. Values for inhibited after and strontium carbonate fluxes prior to the AN-104 run are placed in the PRE-Run Flux column for comparison with the Post AN-104 run fluxes after cleaning. The \% change column shows the sign and the percentage change going from the PRE-run fluxes to the POST-run fluxes. In all cases, the POST-run fluxes were significantly less than the PRE-run fluxes. It will require further study for us to understand why the filter fluxes do not return to PRE-run conditions and what filter cleaning methods are required for this to be achieved. 
WSRC-TR-2003-00295, REV. 0

SRT-RPP-2003-00137, REV. 0

Table 2-13 Filter Cleaning Data

\begin{tabular}{|c|c|c|c|c|}
\hline Cleaning & TMP & $\begin{array}{l}\text { POST-Run } \\
\text { Flux }\end{array}$ & $\begin{array}{c}\text { PRE-Run } \\
\text { Flux } \\
\end{array}$ & $\%$ \\
\hline Agent & (psi) & $\mathrm{gpm} / \mathbf{f t}^{2}$ & $\mathrm{gpm} / \mathbf{f t}^{2}$ & Change \\
\hline Inhibited Water 1 & 40 & 0.132 & $\mathrm{~N} / \mathrm{A}$ & $\mathrm{N} / \mathrm{A}$ \\
\hline Inhibited Water 2 foamed & 40 & 0.079 & $\mathrm{~N} / \mathrm{A}$ & $\mathrm{N} / \mathrm{A}$ \\
\hline Inhibited Water 3 foamed & 40 & 0.042 & $\mathrm{~N} / \mathrm{A}$ & $\mathrm{N} / \mathrm{A}$ \\
\hline Inhibited Water 4 foamed & 40 & 0.026 & $\mathrm{~N} / \mathrm{A}$ & $\mathrm{N} / \mathrm{A}$ \\
\hline 1M Nitric Acid 1 & 40 & 0.282 & $\mathrm{~N} / \mathrm{A}$ & $\mathrm{N} / \mathrm{A}$ \\
\hline 1M Nitric Acid 2 & 40 & 0.163 & $\mathrm{~N} / \mathrm{A}$ & $\mathrm{N} / \mathrm{A}$ \\
\hline 1M Nitric Acid 3 & 40 & 0.45 & $\mathrm{~N} / \mathrm{A}$ & $\mathrm{N} / \mathrm{A}$ \\
\hline 1M Nitric Acid 4 & 40 & 0.439 & $\mathrm{~N} / \mathrm{A}$ & $\mathrm{N} / \mathrm{A}$ \\
\hline 1M Nitric Acid 5 & 40 & 1.19 & $\mathrm{~N} / \mathrm{A}$ & $\mathrm{N} / \mathrm{A}$ \\
\hline 0.01 M Nitric Acid 1 & 40 & 0.383 & $\mathrm{~N} / \mathrm{A}$ & $\mathrm{N} / \mathrm{A}$ \\
\hline $0.01 \mathrm{M}$ Nitric Acid 2 & 40 & 0.445 & $\mathrm{~N} / \mathrm{A}$ & $\mathrm{N} / \mathrm{A}$ \\
\hline Inhibited Water 5 & 40 & 0.531 & $\mathrm{~N} / \mathrm{A}$ & $\mathrm{N} / \mathrm{A}$ \\
\hline Inhibited Water 6 & 10 & 0.108 & .34 & $-67 \%$ \\
\hline Inhibited Water 6 & 20 & 0.195 & .63 & $-69 \%$ \\
\hline Inhibited Water 6 & 30 & 0.34 & omitted & $\mathrm{N} / \mathrm{A}$ \\
\hline $\mathrm{SrCO} 3$ & 10 & 0.112 & .25 & $-55 \%$ \\
\hline $\mathrm{SrCO} 3$ & 20 & 0.29 & .44 & $-34 \%$ \\
\hline $\mathrm{SrCO} 3$ & 30 & 0.15 & .62 & $-76 \%$ \\
\hline Inhibited Water 7 & 20 & 0.091 & .31 & $-71 \%$ \\
\hline
\end{tabular}


WSRC-TR-2003-00295, REV. 0

SRT-RPP-2003-00137, REV. 0

This page intentionally left blank. 
WSRC-TR-2003-00295, REV. 0

SRT-RPP-2003-00137, REV. 0

\subsection{FUTURE WORK}

Perform foaming study to determine the cause of foam and the impact of foam on filter flux.

It will require further study for us to understand why the filter fluxes do not return to PRErun conditions and what filter cleaning methods would be required for this to be achieved. 
WSRC-TR-2003-00295, REV. 0

SRT-RPP-2003-00137, REV. 0

This page intentionally left blank. 


\subsection{REFERENCES}

1. P. S. Townson, "241-AN-104 LAW Entrained Solids Ultrafiltration Test Specification", 24590-PTF-TSP-RT-02-011, Rev. 0, October 17, 2002.

2. M. R. Poirier and P. R. Burket, "Task Technical and Quality Assurance Plan for AN-104 Active Waste Ultrafiltration”, WSRC-TR-2002-00507, SRT-RPP-2002-00249, Rev. 0, November 19, 2002.

3. M.E. Stallings, C.J. Coleman, M.S. Hay, K.B. Martin, "Task Technical and Quality Assurance Plan for Compositing, Homogenizing, and Characterizing Samples from Hanford Tank 241-AN-104", WSRC-TR-2002-00386, SRT-RPP-2002-00199, rev. 0, September 9, 2002.

4. M. R. Poirier, P. R. Burket, and J. L. Siler, "Filtration of a Hanford AW-101 Waste Sample", WSRC-TR-2002-00530, Rev. 0 (SRT-RPP-2002-00263, Rev. 0), February 12, 2003.

5. J. R. Zamecnik, M. A. Baich, E. K. Hansen, and M. R. Poirier, “AN-102 Simulant Sr/TRU Precipitation and Ultrafiltration”, WSRC-TR-2003-00056, Rev. 0 (SRTRPP-2002-00231, Rev. 0), February 10, 2003.

6. M. R. Poirier, P. R. Burket, and J. L. Siler, "Filtration of a Hanford AY-102/C-106 Sample”, WSRC-TR-2002-00530, Rev. 0 (SRT-RPP-2002-00240, Rev. A), June 6, 2003.

7. M.R. Poirier, WSRC-NB-2003-00031, “AN-104 CUF Filtration” Laboratory Notebook.

8. P.R. Burket, "RPP-WTP-AN-104 Filtration Rheology”, SRTC-PDH-2003-00011, July 9, 2003.

9. "Procedure for the Operation of the Shielded Cells Unit Filter (U)", Manual number L12.1, procedure IWT-OP-088, February 9, 2001. 
WSRC-TR-2003-00295, REV. 0

SRT-RPP-2003-00137, REV. 0

This page intentionally left blank. 
WSRC-TR-2003-00295, REV. 0

SRT-RPP-2003-00137, REV. 0

\section{APPENDIX A. FILTER FLUX DATA}

Table A- 1 Filter Flux Data

\begin{tabular}{|c|c|c|c|c|c|c|c|c|c|c|}
\hline \multicolumn{11}{|c|}{ Test 1.3} \\
\hline $\begin{array}{l}\text { Time } \\
\text { (hr) }\end{array}$ & $\begin{array}{c}\text { Tubeside } \\
\text { Exit } \\
\text { Pressure } \\
\text { (psi) }\end{array}$ & $\begin{array}{l}\text { Filtrate } \\
\text { Pressure } \\
\text { (psi) }\end{array}$ & $\begin{array}{l}\text { Slurry } \\
\text { Flowrate } \\
(\text { gpm) }\end{array}$ & $\begin{array}{l}\text { Filtrate } \\
\text { Flowrate } \\
\text { (mL/min) }\end{array}$ & $\begin{array}{c}\text { Tubeside } \\
\text { Inlet } \\
\text { Pressure } \\
\text { (psi) }\end{array}$ & $\begin{array}{l}\text { Slurry } \\
\text { Temp } \\
\text { (C) }\end{array}$ & $\begin{array}{c}\text { Trans- } \\
\text { membrane } \\
\text { Pressure } \\
\text { (psi) }\end{array}$ & $\begin{array}{c}\text { Slurry } \\
\text { Flow } \\
\text { Vel } \\
\text { (ft/s) }\end{array}$ & $\begin{array}{c}\text { Flux@ } \\
\text { Test } \\
\text { Temp } \\
\left(\mathbf{g p m} / \mathbf{f t}^{2}\right)\end{array}$ & $\begin{array}{c}\text { Flux@ } @ \text {. } \\
25^{\circ} \mathbf{C} \\
\left(\mathbf{g p m} / \mathbf{f t}^{2}\right)\end{array}$ \\
\hline 0 & 40 & 0 & 3.74 & N/A & 40 & 25.2 & 40.5 & 10.9 & & \\
\hline 1 & 40 & 0 & 3.89 & N/A & 40 & 21.5 & 41 & 11.3 & Flux & \\
\hline 2 & 40 & 0 & 3.78 & N/A & 40 & 23 & 41 & 11.0 & Data & \\
\hline 3 & 40 & 0 & 3.65 & N/A & 40 & 24.3 & 40 & 10.6 & Table A2 & \\
\hline 4 & 40 & 0 & 3.84 & N/A & 40 & 23.6 & 40 & 11.2 & & Flux \\
\hline 5 & 40 & 0 & 3.87 & N/A & 40 & 26.6 & 40 & 11.2 & & Data \\
\hline 6 & 40 & 0 & 3.27 & $\mathrm{~N} / \mathrm{A}$ & 40 & 24.2 & 40 & 9.5 & & Table A2 \\
\hline 7 & 40 & 0 & 3.19 & N/A & 40 & 25.7 & 40.5 & 9.3 & Flux & \\
\hline 8 & 40 & 0 & 3.7 & N/A & 40 & 22.4 & 40 & 10.7 & Data & \\
\hline 9 & 38 & 0 & 3.7 & N/A & 38 & 25.7 & 40 & 10.7 & Table A2 & \\
\hline 10 & 38 & 0 & 3.62 & $\mathrm{~N} / \mathrm{A}$ & 38 & 23.2 & 40 & 10.5 & & Flux \\
\hline 11 & 38 & 0 & 3.6 & N/A & 38 & 25.6 & 40 & 10.5 & & Data \\
\hline 12 & 38 & 0 & 3.64 & N/A & 38 & 26.9 & 40 & 10.6 & & Table A2 \\
\hline \multicolumn{11}{|l|}{ Test } \\
\hline 1.4 & 40 & 0 & 3.81 & 20.2 & 40 & 29.2 & 40 & 11.1 & 0.028 & 0.025 \\
\hline 1.5 & 40 & 0 & 3.78 & 15 & 40 & 24.9 & 40 & 11 & 0.021 & 0.021 \\
\hline 1.6 & 40 & 0 & 3.78 & 15 & 40 & 25.3 & 40 & 11 & 0.021 & 0.021 \\
\hline 1.7 & 30 & 0 & 3.1 & 11.5 & 30 & 22.5 & 30 & 9 & 0.016 & 0.017 \\
\hline 1.8 & 30 & 0 & 4.53 & 15.2 & 30 & 25.1 & 30 & 13.2 & 0.021 & 0.021 \\
\hline 1.9 & 48 & 0 & 3.71 & 21.4 & 48 & 28.8 & 48 & 10.8 & 0.03 & 0.027 \\
\hline 1.1 & 50 & 0 & 3.09 & 20.3 & 50 & 30 & 50 & 9 & 0.028 & 0.024 \\
\hline 1.11 & 40 & 0 & 3.71 & 13.8 & 40 & 25 & 40 & 10.8 & 0.019 & 0.019 \\
\hline 1.12 & 40 & 0 & 2.37 & 14.1 & 40 & 25 & 40 & 6.9 & 0.02 & 0.02 \\
\hline 1.13 & 40 & 0 & 4.16 & 16.4 & 40 & 30.1 & 40 & 12.1 & 0.023 & 0.02 \\
\hline 1.14 & 20 & 0 & 3.7 & 7.7 & 20 & 25 & 20 & 10.7 & 0.011 & 0.011 \\
\hline 1.15 & 60 & 0 & 3.01 & 18.8 & 60 & 27.8 & 60 & 8.7 & 0.026 & 0.024 \\
\hline 1.16 & 40 & 0 & 3.86 & 12.1 & 40 & 25.3 & 40 & 11.2 & 0.017 & 0.017 \\
\hline
\end{tabular}


WSRC-TR-2003-00295, REV. 0

SRT-RPP-2003-00137, REV. 0

Table A- 2 Test 1.3 Dewatering Flux

\begin{tabular}{|c|c|c|c|c|c|}
\hline \multicolumn{6}{|c|}{ AN-104 Average Dewatering Flux } \\
\hline $\begin{array}{c}\text { Volume of } \\
\text { Permeate } \\
\text { Removed }(\mathrm{mL})\end{array}$ & $\begin{array}{c}\text { Flux } \\
\text { x 1000 } \\
\text { gpm/ft }\end{array}$ & $\begin{array}{l}\text { Volume } x \\
\text { Flux }\end{array}$ & $\begin{array}{c}\text { Temperature } \\
{ }^{0} \mathrm{C}\end{array}$ & $\begin{array}{c}\text { Temperature } \\
\text { Corrected } \\
@ 25^{\circ} \mathrm{C} \\
\end{array}$ & $\begin{array}{l}\text { Volume } \\
\text { x Flux }\end{array}$ \\
\hline 250 & 236 & 59000 & 24 & 243 & 60690 \\
\hline 250 & 146 & 36500 & 24 & 150 & 37546 \\
\hline 250 & 110 & 27500 & 24.3 & 112 & 28049 \\
\hline 250 & 81 & 20250 & 24 & 83 & 20830 \\
\hline 250 & 128 & 32000 & 23 & 136 & 33866 \\
\hline 250 & 78 & 19500 & 23 & 83 & 20637 \\
\hline 250 & 61 & 15250 & 23.3 & 64 & 16002 \\
\hline 230 & 51 & 11730 & 23.6 & 53 & 12204 \\
\hline 250 & 68 & 17000 & 24 & 70 & 17487 \\
\hline 210 & 38 & 7980 & 26.6 & 36 & 7630 \\
\hline 250 & 53 & 13250 & 23 & 56 & 14023 \\
\hline 140 & 52 & 7280 & 23.3 & 55 & 7639 \\
\hline 250 & 49 & 12250 & 24.2 & 50 & 12530 \\
\hline 250 & 48 & 12000 & 24 & 49 & 12344 \\
\hline 250 & 63 & 15750 & 22.2 & 68 & 17054 \\
\hline 250 & 50 & 12500 & 22.5 & 54 & 13419 \\
\hline 215 & 45 & 9675 & 22.5 & 48 & 10387 \\
\hline Average & Average & Average & & & \\
\hline \multirow[t]{3}{*}{238} & 80 & 19377 & & & 20137 \\
\hline & \multicolumn{2}{|c|}{$\begin{array}{l}\text { Weighted Average of } \\
\text { Flux }\end{array}$} & & \multicolumn{2}{|c|}{$\begin{array}{l}\text { Weighted Average of } \\
\text { Flux }\end{array}$} \\
\hline & @ Temp & 0.081 & & @ $25 \mathrm{C}$ & 0.085 \\
\hline
\end{tabular}


WSRC-TR-2003-00295, REV. 0

SRT-RPP-2003-00137, REV. 0

\title{
APPENDIX B. FILTER FLUX STATISTICAL DATA
}

\section{JMP ${ }^{\circledR}$ Statistical Analysis of AN-104 Filtration Test Matrix Data}

\author{
Response Flux@25 \\ Whole Model \\ Summary of Fit \\ RSquare $\quad 0.647356$ \\ RSquare Adj $\quad 0.576827$ \\ Root Mean Square Error $\quad 0.00269$ \\ Mean of Response $\quad 0.020538$ \\ Observations (or Sum Wgts) 13 \\ Analysis of Variance

$\begin{array}{lrrrr}\text { Source } & \text { DF } & \text { Sum of Squares } & \text { Mean Square } & \text { F Ratio } \\ \text { Model } & 2 & 0.00013286 & 0.000066 & 9.1786 \\ \text { Error } & 10 & 0.00007237 & 0.000007 & \text { Prob }>\text { F } \\ \text { C. Total } & 12 & 0.00020523 & & 0.0055 \\ \text { Lack Of Fit } & & & & \\ \text { Source } & \text { DF } & \text { Sum of Squares } & \text { Mean Square } & \text { F Ratio } \\ \text { Lack Of Fit } & 9 & 0.00007237 & 0.000008 & \\ \text { Pure Error } & 1 & 0.00000000 & 0 & \text { Prob }>\text { F } \\ \text { Total Error } & 10 & 0.00007237 & & \text { Max RSq } \\ & & & & 1.0000\end{array}$ \\ Parameter Estimates

$\begin{array}{lrrrr}\text { Term } & \text { Estimate } & \text { Std Error } & \mathrm{t} \text { Ratio } & \text { Prob }>|t| \\ \text { Intercept } & -0.000116 & 0.007148 & -0.02 & 0.9874 \\ \text { TMP } & 0.0003581 & 0.000084 & 4.28 & 0.0016 \\ \text { Axial Vel } & 0.0006126 & 0.000504 & 1.21 & 0.2525\end{array}$ \\ Effect Tests \\ $\begin{array}{lrrrrr}\text { Source } & \text { Nparm } & \text { DF } & \text { Sum of Squares } & \text { F Ratio } & \text { Prob }>\text { F } \\ \text { TMP } & 1 & 1 & 0.00013246 & 18.3025 & 0.0016 \\ \text { Axial Vel } & 1 & 1 & 0.00001067 & 1.4745 & 0.2525\end{array}$ \\ Probability TMP $<0.05$, TMP statistically significant \\ Probability Axial Velocity $>0.05$, axial velocity not statistically significant.
}


WSRC-TR-2003-00295, REV. 0

SRT-RPP-2003-00137, REV. 0

This page intentionally left blank 
WSRC-TR-2003-00295, REV. 0

SRT-RPP-2003-00137, REV. 0

\section{APPENDIX C. ANALYTICAL REQUIREMENTS}

\section{Analytical Requirements for Filtrate, Washed Solids, Wash Solutions}

\begin{tabular}{|c|c|c|}
\hline Analyte & $\begin{array}{c}\text { Washed Solids } \\
\text { Minimum Reportable } \\
\text { Quantity (MRQ) } \mu \mathrm{Ci} / \mathrm{gm}\end{array}$ & $\begin{array}{c}\text { Filtrate, Wash Solutions } \\
\text { Minimum Reportable Quantity } \\
(\mathrm{MRQ}) \mu \mathrm{Ci} / \mathrm{mL}\end{array}$ \\
\hline Cesium-137 & $6.0 \mathrm{E}-02$ & $9.0 \mathrm{E}+00$ \\
\hline Strontium-90 & $7.01 \mathrm{E}+01$ & $1.5 \mathrm{E}-01$ \\
\hline Technetium-99 & $6 \mathrm{E}+00 \mu \mathrm{gm} / \mathrm{gm}$ & $1.5 \mathrm{E}-03$ \\
\hline Americium-241 & $1.2 \mathrm{E}-03$ & $7.2 \mathrm{E}-04$ \\
\hline Europium-154 & $6.0 \mathrm{E}-02$ & $2.0 \mathrm{E}-03$ \\
\hline Europium-155 & $6.0 \mathrm{E}-02$ & $9.0 \mathrm{E}-02$ \\
\hline $\mathrm{Pu}-239 / 240$ & $6.0 \mathrm{E}+00 \mu \mathrm{Ci} / \mathrm{gm}$ & $9.6 \mathrm{E}-03$ \\
\hline \multirow[t]{2}{*}{ Total Alpha/Beta } & $1.0 \mathrm{E}-03$ & $2.3 \mathrm{E}-01$ \\
\hline & $\mu \mathrm{gm} / \mathrm{gm}$ & $\mu \mathrm{gm} / \mathrm{mL}$ \\
\hline $\mathrm{Ag}$ & $2.0 \mathrm{E}+01$ & $\mathrm{~N} / \mathrm{A}$ \\
\hline $\mathrm{Al}$ & $3.3 \mathrm{E}+02$ & $7.5 \mathrm{E}+01$ \\
\hline As & $6.0 \mathrm{E}+02$ & $\mathrm{~N} / \mathrm{A}$ \\
\hline $\mathrm{Ba}$ & $6.0 \mathrm{E}+02$ & $7.8 \mathrm{E}+01$ \\
\hline $\mathrm{Be}$ & $1.5 \mathrm{E}+02$ & $\mathrm{~N} / \mathrm{A}$ \\
\hline $\mathrm{Ca}$ & $1.8 \mathrm{E}+02$ & $1.5 \mathrm{E}+02$ \\
\hline $\mathrm{Cd}$ & $1.1 \mathrm{E}+01$ & $7.5 \mathrm{E}+00$ \\
\hline $\mathrm{Co}$ & $3.0 \mathrm{E}+00$ & $3.0 \mathrm{E}+01$ \\
\hline $\mathrm{Cr}$ & $1.2 \mathrm{E}+02$ & $1.5 \mathrm{E}+01$ \\
\hline $\mathrm{Cu}$ & $1.8 \mathrm{E}+01$ & $1.7 \mathrm{E}+01$ \\
\hline $\mathrm{Fe}$ & $1.4 \mathrm{E}+02$ & $1.5 \mathrm{E}+02$ \\
\hline $\mathrm{Hg}$ & $3.0 \mathrm{E}+00$ & $1.5 \mathrm{E}+00$ \\
\hline $\mathrm{K}$ & $1.5 \mathrm{E}+03$ & $7.5 \mathrm{E}+01$ \\
\hline $\mathrm{La}$ & $6.0 \mathrm{E}+01$ & $3.5 \mathrm{E}+01$ \\
\hline $\mathrm{Mg}$ & $5.4 \mathrm{E}+02$ & $1.5 \mathrm{E}+02$ \\
\hline $\mathrm{Mn}$ & $3.0 \mathrm{E}+02$ & $1.5 \mathrm{E}+02$ \\
\hline Mo & $6.0 \mathrm{E}+00$ & $9.0 \mathrm{E}+01$ \\
\hline $\mathrm{Na}$ & $1.5 \mathrm{E}+02$ & $7.5 \mathrm{E}+01$ \\
\hline $\mathrm{Ni}$ & $1.6 \mathrm{E}+02$ & $3.0 \mathrm{E}+01$ \\
\hline $\mathrm{Pb}$ & $6.0 \mathrm{E}+02$ & $3.0 \mathrm{E}+02$ \\
\hline $\mathrm{Sb}$ & $1.5 \mathrm{E}+02$ & $\mathrm{~N} / \mathrm{A}$ \\
\hline $\mathrm{Se}$ & $7.5 \mathrm{E}+02$ & $\mathrm{~N} / \mathrm{A}$ \\
\hline $\mathrm{Si}$ & $3.0 \mathrm{E}+03$ & $1.7 \mathrm{E}+02$ \\
\hline $\mathrm{Sr}$ & $3.0 \mathrm{E}+02$ & $6.5 \mathrm{E}-01$ \\
\hline $\mathrm{Ti}$ & $1.5 \mathrm{E}+02$ & $1.7 \mathrm{E}+01$ \\
\hline $\mathrm{Tl}$ & $3.0 \mathrm{E}+01$ & $\mathrm{~N} / \mathrm{A}$ \\
\hline $\mathrm{U}$ & $6.0 \mathrm{E}+02$ & $6.0 \mathrm{E}+02$ \\
\hline $\mathrm{Zn}$ & $6.0 \mathrm{E}+00$ & $1.65 \mathrm{E}+01$ \\
\hline $\mathrm{TOC}$ & $6.0 \mathrm{E}+01$ & $1.5 \mathrm{E}+03$ \\
\hline TIC & $3.0 \mathrm{E}+01$ & $1.5 \mathrm{E}+02$ \\
\hline $\mathrm{Cl}$ & $2.3 \mathrm{E}+02$ & $3.0 \mathrm{E}+00$ \\
\hline $\mathrm{F}$ & $7.5 \mathrm{E}+03$ & $1.5 \mathrm{E}+02$ \\
\hline NO3 & $*$ & $3.0 \mathrm{E}+03$ \\
\hline $\mathrm{SO} 4$ & $1.2 \mathrm{E}+03$ (as S) & $2.3 \mathrm{E}+03$ \\
\hline PO4 & $6.0 \mathrm{E}+02$ (as P) & $2.5 \mathrm{E}+03$ \\
\hline
\end{tabular}

Nitrate concentration in solids will not be measured.

N/A NOT APPLICABLE 
WSRC-TR-2003-00295, REV. 0

SRT-RPP-2003-00137, REV. 0

This page intentionally left blank. 
WSRC-TR-2003-00295, REV. 0

SRT-RPP-2003-00137, REV. 0

\section{APPENDIX D. SCANNING ELECTRON MICROSCOPE PICTURES OF SOLIDS PARTICLES}

2.3kX SE\&BS
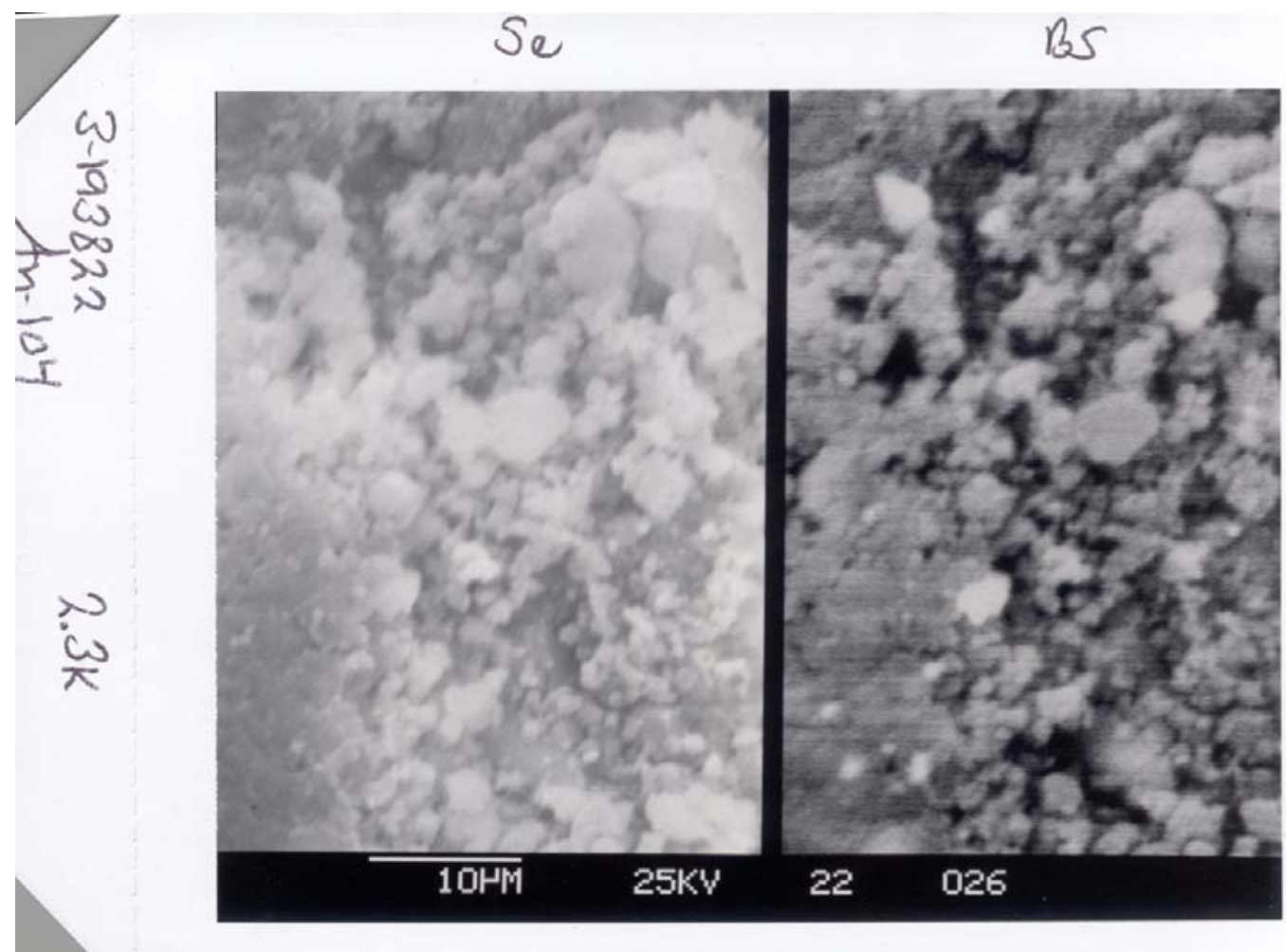
WSRC-TR-2003-00295, REV. 0

SRT-RPP-2003-00137, REV. 0

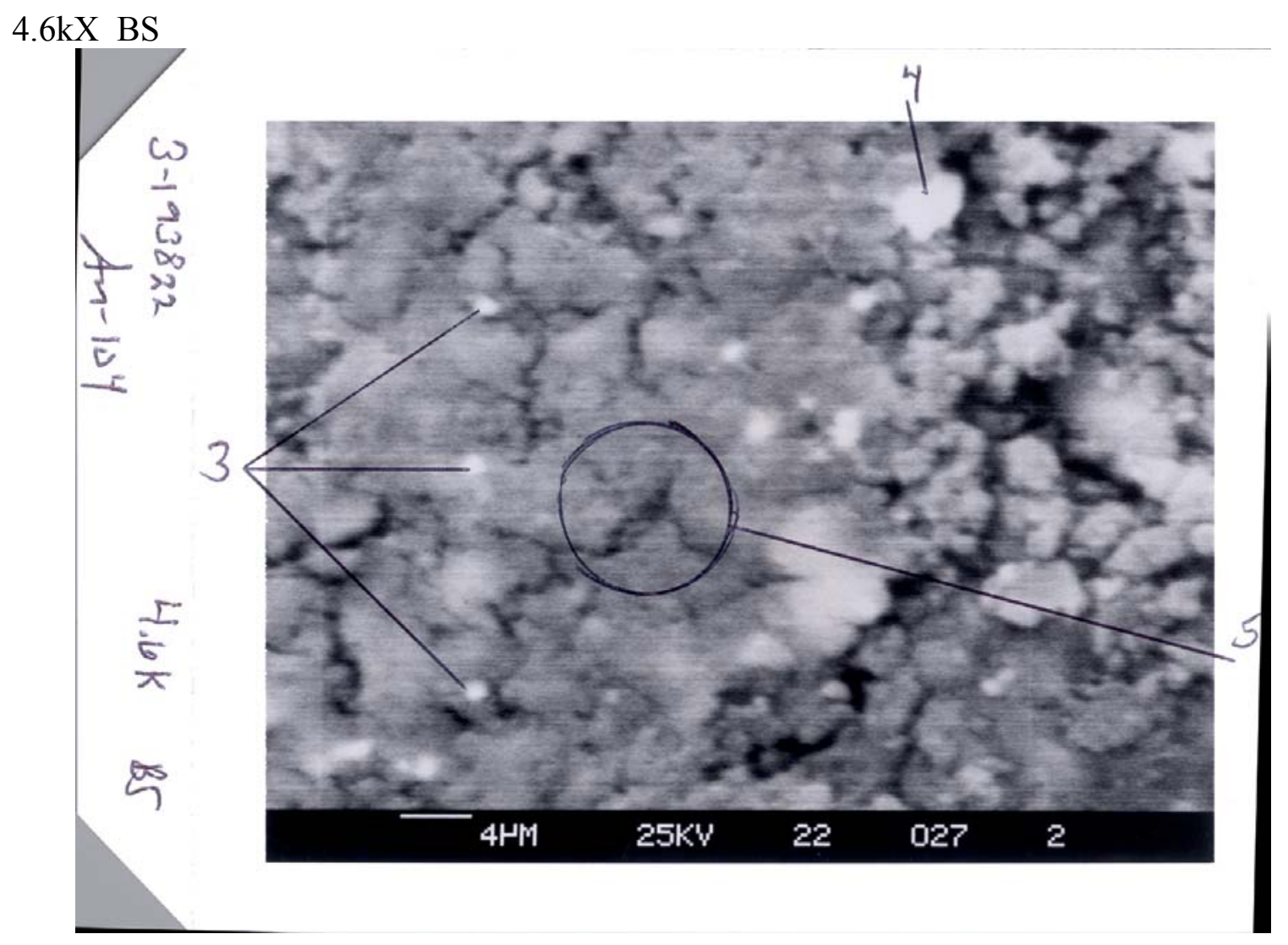

4.6kX SE

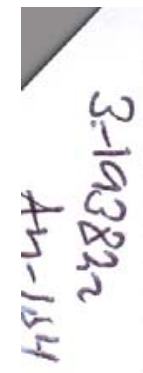

$\frac{5}{\frac{\pi}{\pi}}$

$\infty_{\infty}$

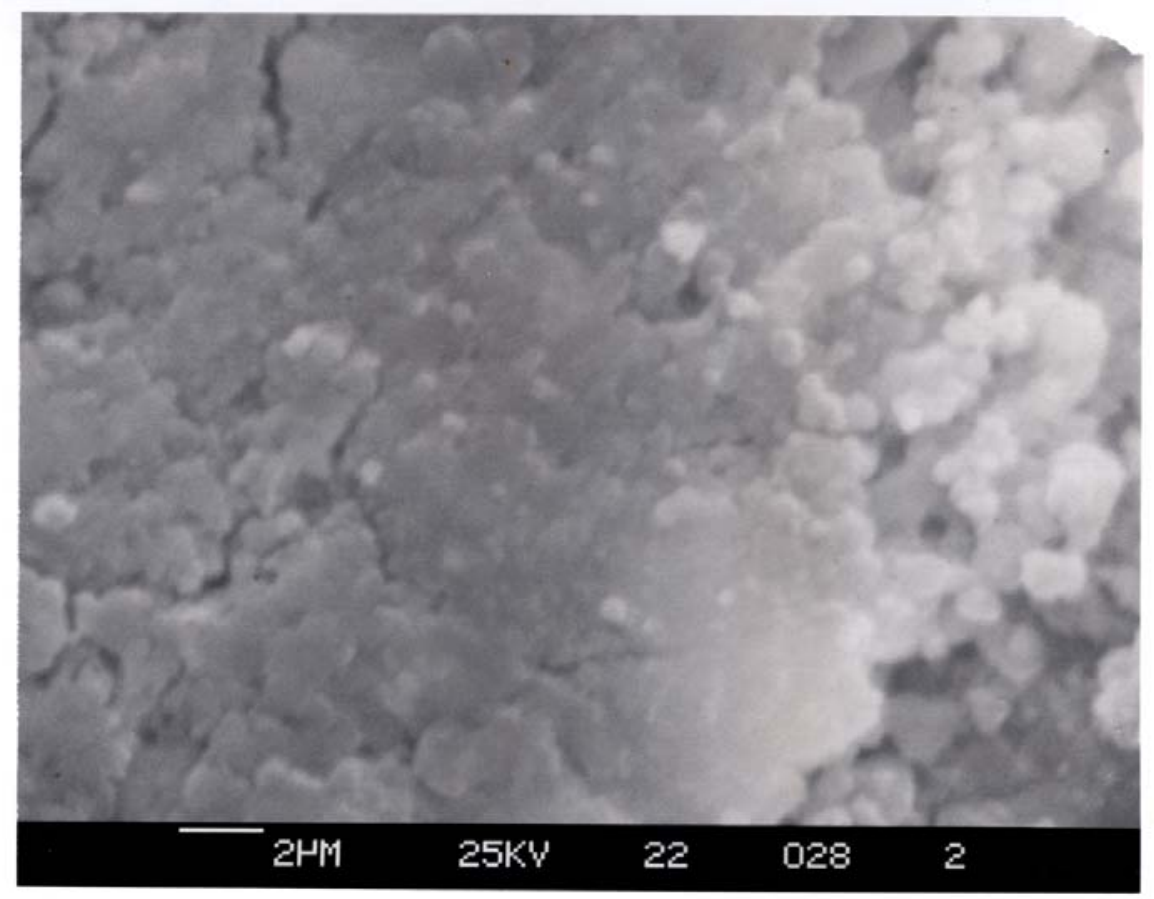


WSRC-TR-2003-00295, REV. 0

SRT-RPP-2003-00137, REV. 0

41X BS
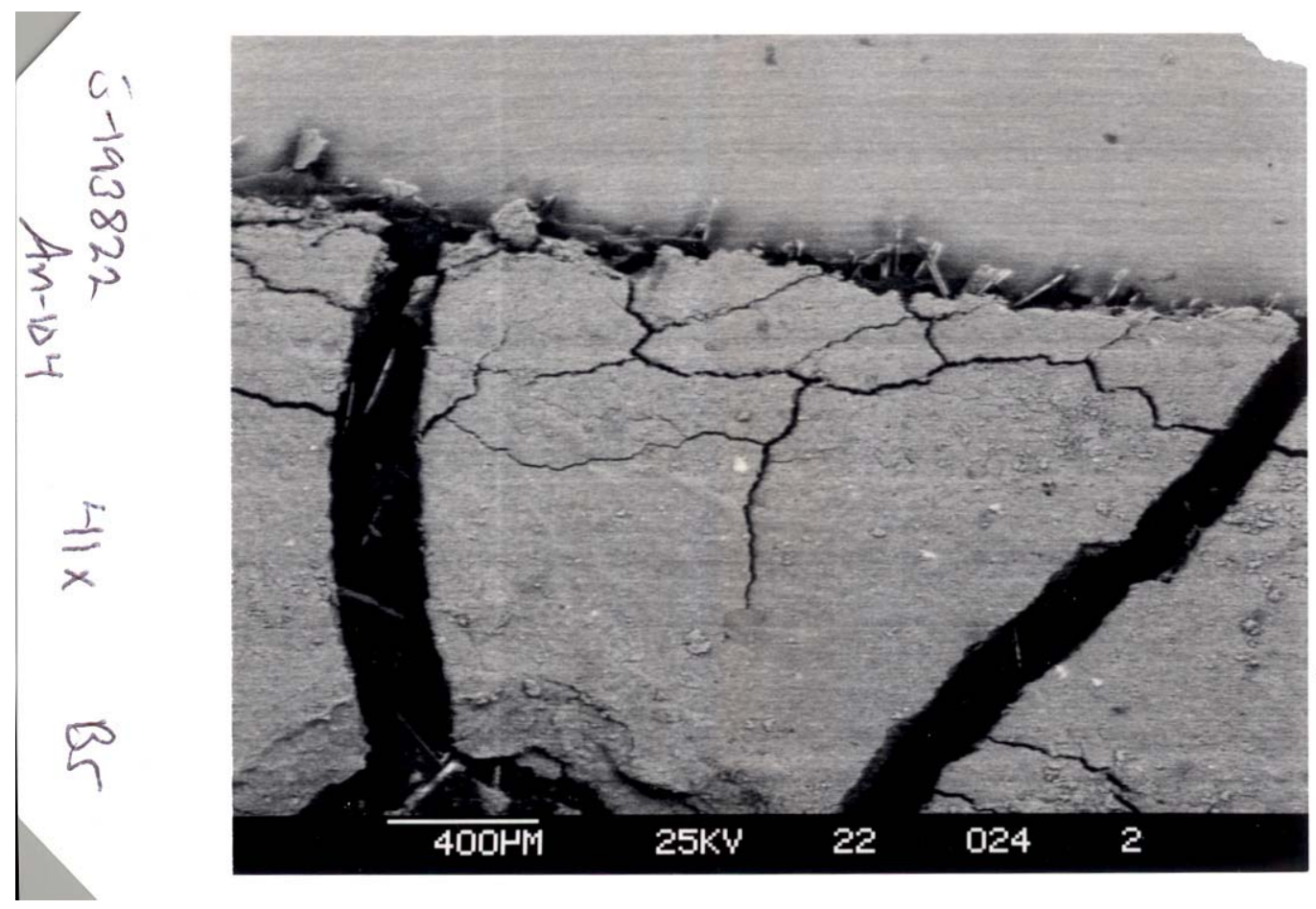

41X SE

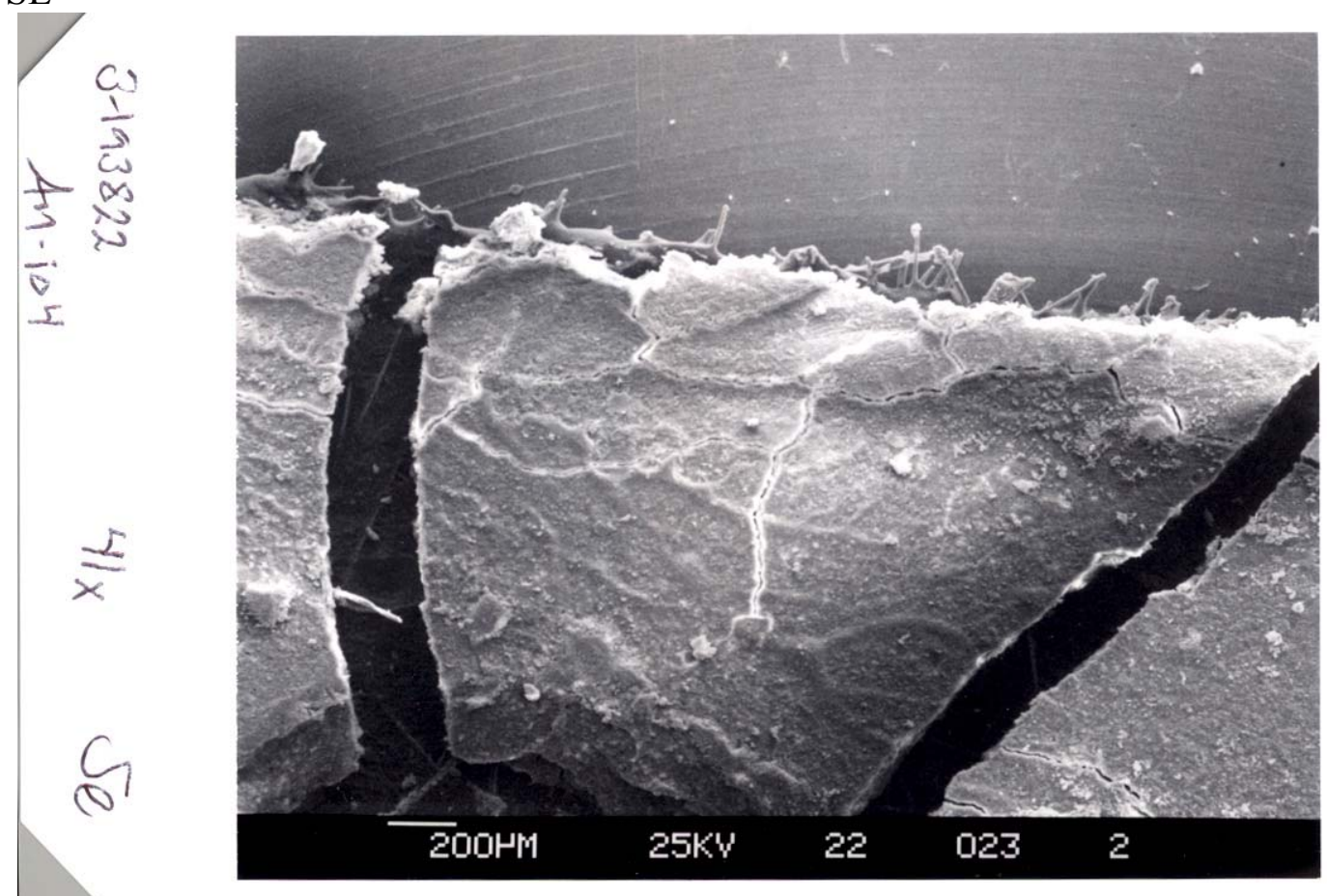


WSRC-TR-2003-00295, REV. 0

SRT-RPP-2003-00137, REV. 0

333X BS

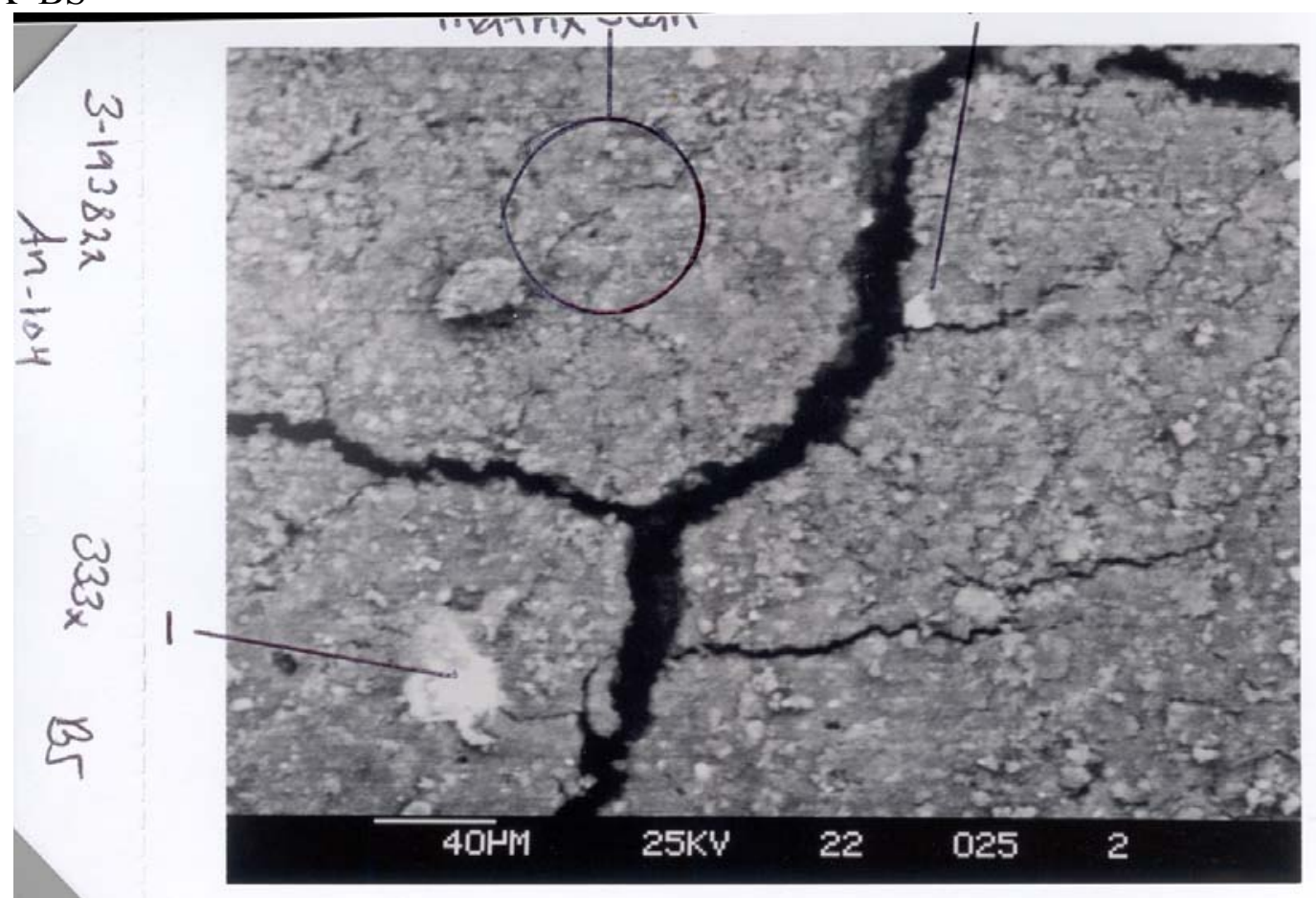

